\title{
1. IMPACT OF SILICA DIAGENESIS ON PHYSICAL PROPERTY VARIATIONS ${ }^{1}$
}

\author{
David C. Nobes, ${ }^{2}$ Richard W. Murray, ${ }^{3}$ Shin'ichi Kuramoto, ${ }^{4}$ Kenneth A. Pisciotto, ${ }^{5}$ and Peter Holler ${ }^{6}$
}

\begin{abstract}
The silica diagenetic boundaries, especially the transition from opal-A to opal-CT, are significant seismic and thermal horizons in the Japan Sea. Diagenesis has a marked effect on laboratory and downhole logging physical properties. Index property residues were used for X-ray diffraction and scanning electron microscopy studies that complement the physical property and logging data so that we may examine the diagenetic transitions in some detail. We identify the sharpest physical property gradients with the opal-A/opal-CT boundaries for each site; in a number of cases, the boundaries are different from those previously defined. The changes in the physical properties, especially the acoustic velocity, are distinct across the opal-A/opal-CT boundary. The thickness of the opal-A to opal-CT transition zone depends on the way in which the zone is defined. If we interpret the diagenetic transition zone to be between the point where a clear-cut change or trend starts, to the point where the changes are indistinguishable from the natural background variability, then the zone can be $10 \mathrm{~m}$ or more thick. The profiles of the various physical properties are often parallel, and begin to change well above the diagenetic boundary. This is consistent with the shallow occurrence of opal-CT. The opal-CT to quartz transformation, in contrast, is rapid, and the transition zone is at most $1 \mathrm{~m}$ thick. The physical property changes are not as distinct across the opal-CT/quartz boundary.
\end{abstract}

\section{INTRODUCTION}

\section{Silica Diagenesis}

A transition zone may appear sharp and well defined when observed from a distance, but may be diffuse and broad when examined closely. In defining a transition zone, therefore, we need to determine how sharp or diffuse the zone may be. In our case, we are interested in the diagenesis of amorphous opal (opal-A) to opal-CT, and of opal-CT to quartz. We have constructed data sets of X-ray diffraction (XRD) measurements using index property residues, which complement the index property and downhole logging data. In addition, some of the residues were studied using scanning electron microscopy (SEM). We may thus examine the opal-A to opal-CT and opal-CT to quartz transition zones in detail through direct correlation of the core and logging properties. The downhole logging data can be used to construct a high-resolution record of the changes, both chemical and physical, across the diagenetic boundaries, so that we may gain a better understanding of the opal-A to opal-CT, and the opal-CT to quartz processes and their effects on the physical properties.

Going downhole, diagenesis is progressive, and opal-A and opal-CT generally co-exist over some interval; opal-CT and quartz similarly overlap (Pisciotto, 1981a, 1981b). The transformations, however, appear to occur within a relatively short distance (Pisciotto, 1981a, 1981b; Kastner and Gieskes, 1983; Tada and Iijima, 1983), and at each transition, a significant reduction in porosity has been observed (Isaacs et al., 1983; Tada, 1991). The rate is generally dependent on temperature (Kastner and Gieskes, 1983) and sedimentation rate (Pisciotto, 1981a, 1981b), and may also be controlled by the lithology and pore-water environment. For example, the presence of carbonate

'Pisciotto, K. A., Ingle, J. C., Jr., von Breymann, M. T., Barron, J., et al., 1992. Proc. ODP, Sci. Results, 127/128, Pt. 1: College Station, TX (Ocean Drilling Program).

${ }^{2}$ Department of Earth Sciences and Department of Physics, University of Waterloo, Waterloo, Ontario N2L 3G1, Canada. (Present address: Department of Geology, University of Canterbury, Private Bag 4800, Christchurch, New Zealand.)

Department of Geology and Geophysics, University of California at Berkeley, Berkeley, CA 94720, U.S.A. (Present address: Graduate School of Oceanography, University of Rhode Island, Narragansett, RI 02882 , U.S.A.)

Ocean Research Institute, University of Tokyo, 1-15-1, Minimadai, Nakano-ku, Tokyo 164, Japan.

B.P. Exploration Company Ltd., Britannic House, Moore Lane, London EC2Y 9BU, United Kingdom. may promote silica diagenesis, yet clay may retard the opal-A to opal-CT transformation (Kastner et al., 1977; Kastner and Gieskes, 1983). Opal-CT is further cemented at higher temperatures and greater depths, and the (101) d-spacing of opal-CT changes as a function of the temperature (Iijima and Tada, 1981; Pisciotto, 1981a, 1981b).

\section{Preliminary Observations from the Japan Sea}

The diagenetic transition from opal-A to opal-CT is correlated with a significant seismic reflector across the Japan Sea (Shipboard Scientific Party, 1990a; Kuramoto et al., this volume). The relatively narrow temperature range over which this diagenetic transformation occurs also allows this horizon to be used as a thermal marker in the Japan Sea (Kuramoto et al.; Langseth et al., both this volume). The sites drilled on Legs 127 and 128 form an approximately north-south transect (Fig. 1), and these seismic and thermal horizons have been sampled across the basin. The opal-A/opal-CT boundary occurs at or near a lithologic boundary (Fig. 2), whereas the opal-CT/quartz boundary often lies within a lithologic unit and does not appear to be as distinct as the transition from opal-A to opal-CT. The porosity decreases markedly across the opal-A/opal-CT boundary (Fig. 3), thus giving rise to the observed seismic reflector. The opal-CT/quartz boundary is less well defined in the porosity profiles, though that may be a byproduct of poor core recovery below the opal-A/opal-CT boundary. At this scale, then, these observations suggest that the transition from opal-A to opal-CT is sharp and distinct.

That is indeed how the silica diagenetic transitions appear when downhole logging data are examined across a broad depth range that encompasses both diagenetic transition zones; Site 797 is an example (Fig. 4). In each case, the computed $\mathrm{Th}+\mathrm{K}$ gamma-ray yield increases sharply, as do the resistivity (measured using the medium induction $\log$ ), the median velocity, the $\mathrm{Al}$ yield, and the porosity indicator ratio (PIR). The variability in the velocity, resistivity, and gamma-ray yield in the opal-CT layer is large but becomes much more subdued just above the opal-CT to quartz transition, where again the gamma-ray and AI yields and the PIR increase sharply.

In contrast to the relatively sharp boundaries present in the logs, diatoms persist to some depth below the opal-A to opal-CT boundary, and hard, cherty layers alternate with softer layers so that opal-A dissolution and subsequent opal-CT precipitation does not occur suddenly and completely nor does it occur uniformly. The presence of alternating harder and softer layers causes problems for drilling and core recovery. The opal-CT to quartz transition was not as well 


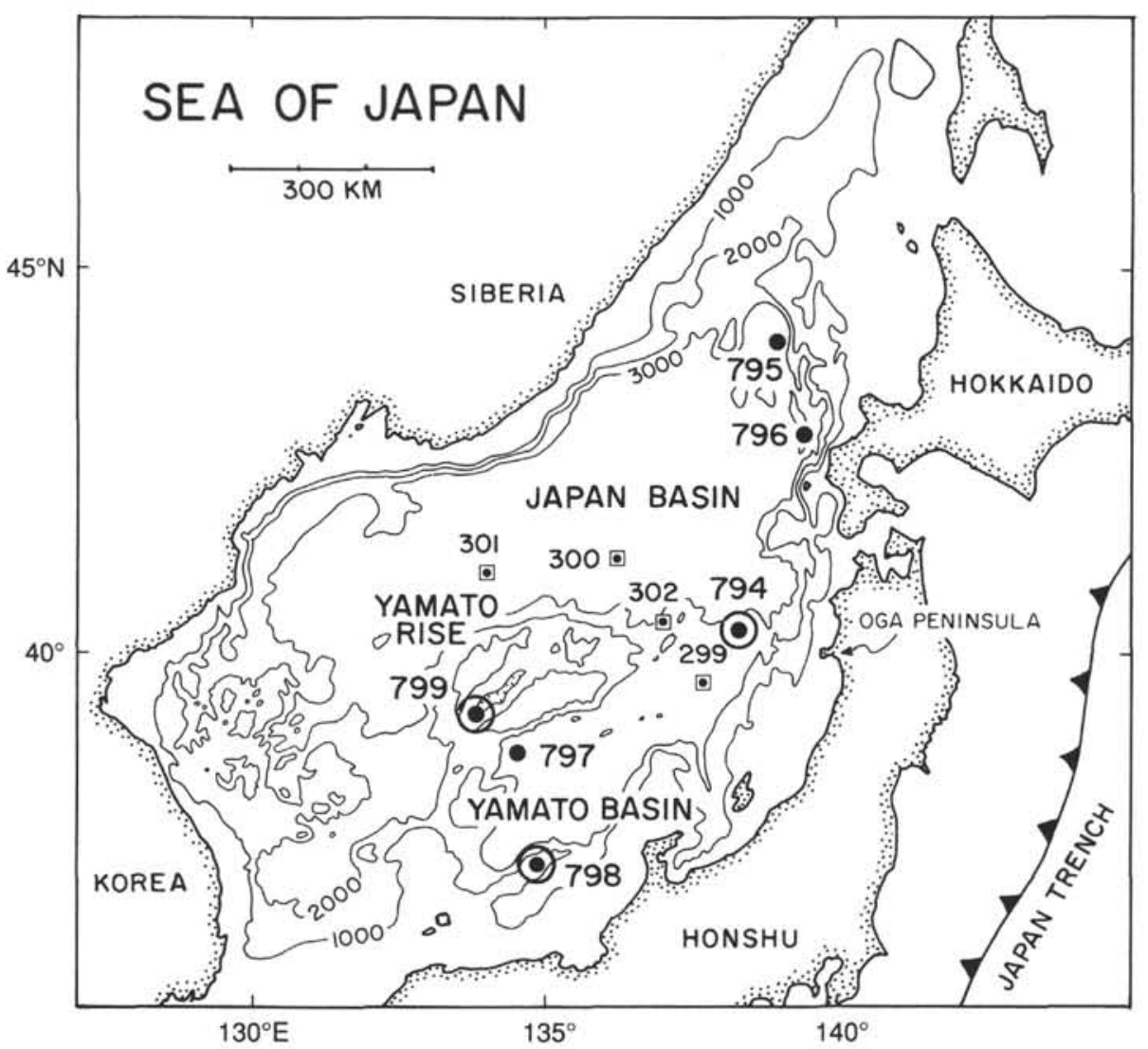

Figure 1. Locations of site drilled during Legs 127 and 128 (from Shipboard Scientific Party, 1990d). Leg 128 sites are circled; Site 794 was drilled on both legs. The sites are on an approximate north-south line, from the northern Japan Basin (Site 795) to Oki Ridge (Site 798). DSDP Sites 299 to 302 are also shown.

defined using shipboard analyses, in part due to poor core recovery below the opal-A/opal-CT boundary.

Our goal, therefore, is to characterize the physical changes that occur in association with the diagenetic changes. We thus compare the shipboard physical property and downhole logging measurements with XRD and SEM studies. In particular, the physical property residues have been used for XRD analyses and for SEM examination in order to obtain complementary sets of data.

\section{LITHOLOGY AND SAMPLING}

As we have already noted, the lithology from site to site in the Japan Sea is similar (Fig. 2), and the opal-A to opal-CT transitions occur at or near lithologic unit boundaries. The opal-A/opal-CT and opal-CT/quartz boundaries marked on the figures are those boundaries defined from shipboard analyses. Our results in many cases lead to an adjustment of the positions of the diagenetic boundaries. Whenever the diagenetic boundaries are mentioned, the boundaries defined on the basis of shipboard studies will be so indicated.

The coarse similarity in lithology is present in the physical properties as well, as illustrated by the porosity (Fig. 3). There are, however, variations from site to site, both in lithology and in the physical properties. A detailed sampling program for XRD and SEM studies was restricted to Sites 795 and 797 , where X-ray fluorescence (XRF) and interstitial water studies were also carried out (Murray et al., this volume). While the lithologies at the two sites are similar, there are significant differences. Site 795 is located at the northern end of the Japan Basin, and Site 797 is located in the southwestern portion of the Yamato Basin, at almost the opposite end of the Japan Sea.

\section{Site 795 Sedimentary Characteristics and Lithologic Units}

The sedimentary sequence at Site 795 consists of four lithologic units (Shipboard Scientific Party, 1990f). Unit I (0 to 123 meters below seafloor, or mbsf) is composed of silty clay, diatomaceous clay, and clay. Subunit IA ( 0 to $85 \mathrm{mbsf}$ ) has numerous discrete thin ash beds; Subunit IB ( 85 to $123 \mathrm{mbsf}$ ) contains more clay and proportionately fewer diatoms than Subunit IA. Unit II (123 to $239 \mathrm{mbsf}$ ) is a diatom ooze and mixed silty clay-diatom ooze. Ash layers are rare.

Units III and IV contain the major silica diagenetic boundaries. Unit III ( 239 to $325 \mathrm{mbsf}$ ) is composed of diatomaceous claystone and siltstone. Subunit IIIA ( 239 to $288.8 \mathrm{mbsf}$ ) contains diatomaceous claystone and silty diatomaceous claystone; Subunit IIIB (307.9 to $325 \mathrm{mbsf}$ ) is a thinner sequence of diatomaceous clayey siltstone and mixed diatom ooze, silt, and clay. The diatom and silt content of IIIB is higher than in IIIA, with a corresponding decrease in the clay content. The base of Unit III is marked by the opal-A to opal-CT transition at $325 \mathrm{mbsf}$, as defined using the shipboard XRD. Unit IV is divided into Subunits IVA (325 to $413 \mathrm{mbsf}$ ) and IVB (413 to $665 \mathrm{mbsf}$ ). Subunit IVA is a siliceous silty claystone marked by poor core recovery due to numerous porcellanite and chert layers; Subunit IVB is composed of siliceous claystone, claystone, and silty siliceous claystone, with tuff layers near the base of the unit. Based on shipboard analyses, the opal-CT to quartz transition occurs in Subunit IVB at about $471 \mathrm{mbsf}$.

\section{Site 797 Sedimentary Characteristics and Lithologic Units}

The sedimentary sequence at Site 797 is divided into six units (Shipboard Scientific Party, 1990h), but we will restrict our dis- 


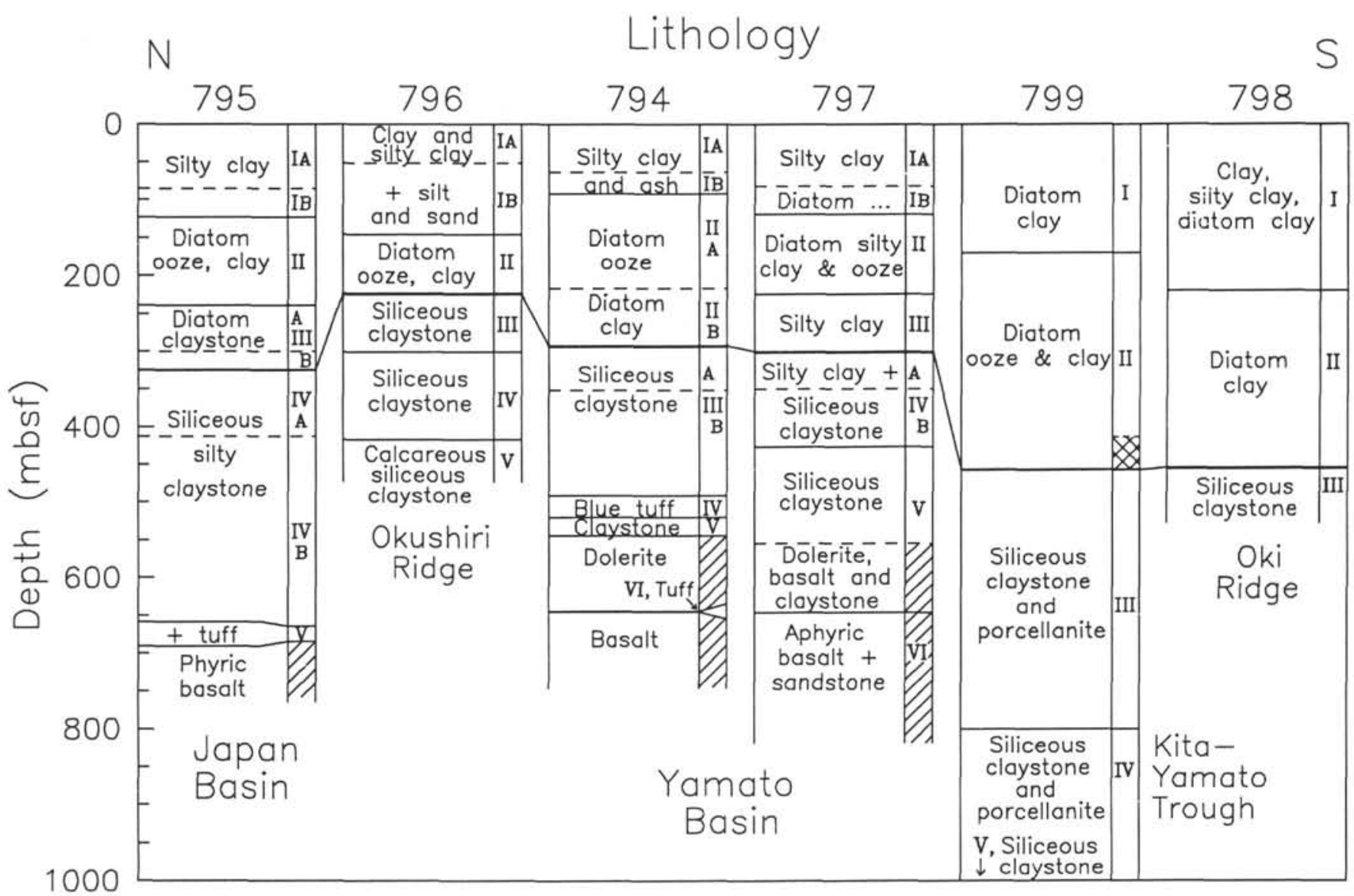

Figure 2. Major lithology from sites drilled during Legs 127 and 128, in an approximate north-south transect. The opal-A/opal-CT transition, as defined by shipboard XRD analyses, occurs at unit boundaries and is marked by a bold line connected from site to site. The first appearance of opal-CT to the disappearance of diatoms occurs across a broad zone at Site 799, shown as a cross-hatched area (Shipboard Scientific Party, 1990j). The igneous units are shown as hatched areas. (Adapted from Tamaki, Pisciotto, Allan, et al., 1990, and Ingle, Suyehiro, von Breymann, et al., 1990.)

cussion to the upper four units which lie entirely above the intercalated igneous and sedimentary complexes. Unit I ( 0 to 119.9 mbsf $)$ is primarily composed of silty clay and clay. The number of ash layers and diatoms increases towards the base of Subunit IA ( 0 to $81.9 \mathrm{mbs})$, and Subunit IB (81.9 to $119.9 \mathrm{mbsf}$ ) is composed of diatom-bearing ashy clay and silty clay. The diatom content increases toward the base of Subunit IB. Unit II (119.9 to $224 \mathrm{mbsf}$ ) is composed of diatomaceous clay, clayey diatom ooze, and diatom ooze. The lower portions of Unit II contain more diatoms than the upper portions.

As at Site 795, Units III and IV are of greatest interest for an examination of silica diagenesis. Unit III ( 224 to $301.5 \mathrm{mbsf}$ ) is a diatomaceous clay and silty claystone with minor amounts of diatom ooze and diatom-bearing claystone. The opal-A to opal-CT transition occurs near the base of Unit III at approximately $299 \mathrm{mbsf}$, based on the shipboard XRD. Unit IV is divided into Subunits A (301.5 to $350 \mathrm{mbsf}$ ) and B (350 to $426.6 \mathrm{mbsf}$ ); Subunit IVA is a claystone and silty claystone with rare chert, whereas IVB consists of a siliceous clay-stone, claystone, porcellanite, and chert. The opal-CT to quartz transition occurs at or near the base of Subunit IVB, again as defined by shipboard analyses.

\section{Sampling}

Physical property samples were taken at regular intervals, about once per section, including those sections encompassing the diage- netic boundaries. By making use of the physical property residues for chemical analysis, we are able to construct complementary data sets for comparison and correlation. Once the index property determinations were completed, the physical property residues were split; one set of residues was subjected to XRF analysis while the companion set was used for SEM and XRD studies. The XRF results are reported elsewhere (Murray et al., this volume). The opal-A/opal-CT and opal-CT/quartz boundaries were defined previously using shipboard analyses (Tamaki, Pisciotto, Allan, et al., 1990; Ingle, Suyehiro, von Breymann, et al., 1990).

The physical property methodology has been presented previously (Shipboard Scientific Party, 1990c; Nobes et al., 1991) and will not be discussed here. The physical properties examined in detail include the acoustic velocity, the thermal conductivity, and a subset of the index properties - the porosity, water content, wet-bulk density, and grain density. In many cases, we also have a detailed density record from the gamma-ray attenuation porosity evaluator (GRAPE). The samples were powdered for the XRD analyses and representative samples were taken, mounted, and gold-coated for SEM examination. XRD scans were acquired using a Siemens D500 diffractometer and a $\mathrm{CuK}_{\alpha}$ source with a step rate of $0.015^{\circ} / \mathrm{s}$ from $12^{\circ}$ to $32^{\circ}(2 \theta)$ for Site 795 . When it was recognized that clinoptilolite was common, especially in Site 797 samples, the $2 \theta$ scan range for Site 797 was set from $8^{\circ}$ to $32^{\circ}$ to obtain the major clinoptilolite peaks at $9 \AA$ and $8 \AA$ ( $2 \theta$ $=9.85^{\circ}$ and $11.3^{\circ}$, respectively). The raw data were gathered in a 


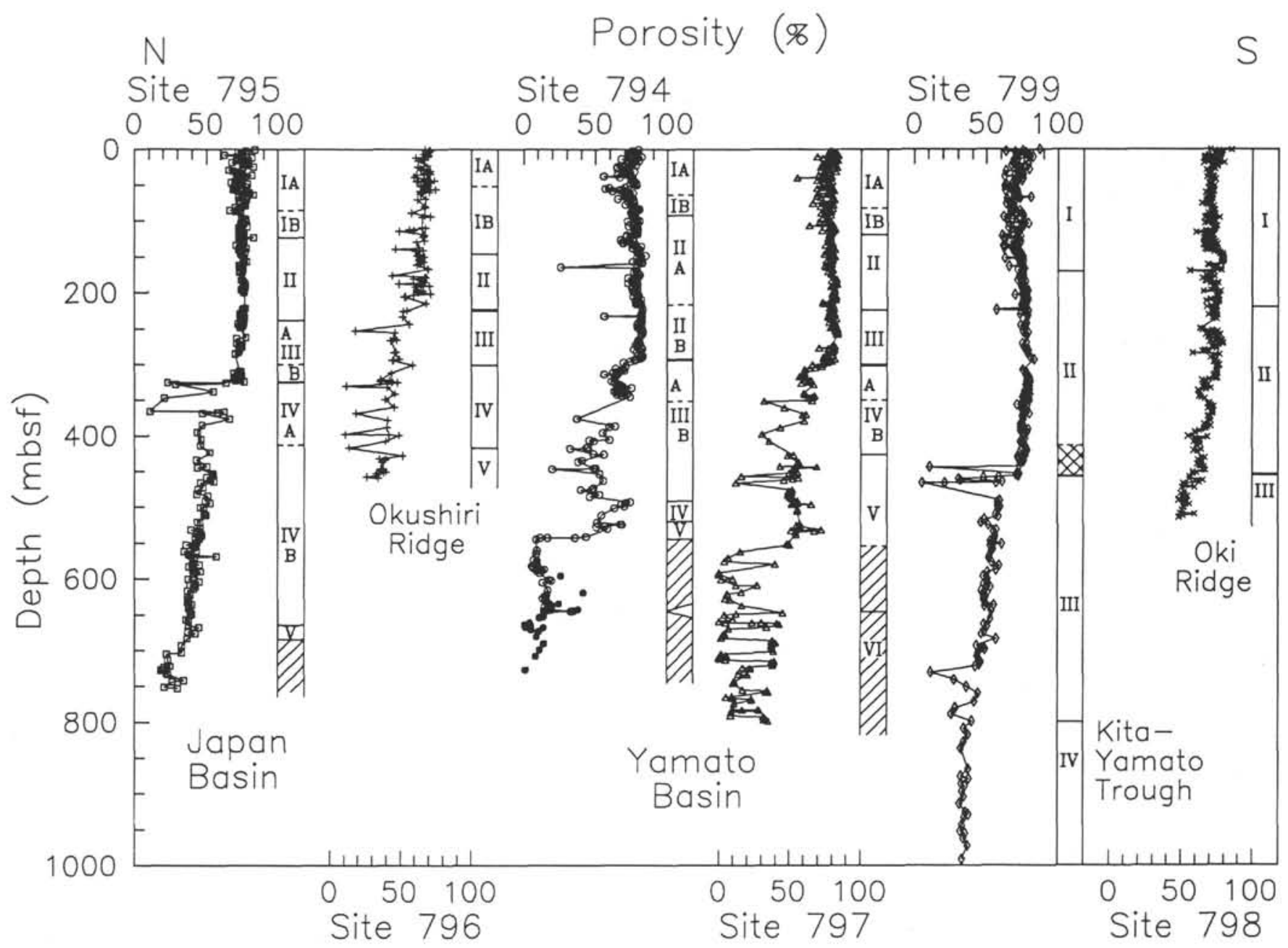

Figure 3. North-south profiles of porosity. The opal-A/opal-CT boundary is marked by a sharp drop from higher to lower porosity. Note the similarity of the Sites 794 and 797 profiles. The opal-A/opal-CT boundaries defined from shipboard XRD analyses are shown by bold lines in the lithologic columns to the right of each of the porosity profiles.

spreadsheet for transfer to a plotting program. The locations of the XRD peaks that could be identified above the background, the raw and normalized intensities, and the possible mineral phases are listed in Tables 1 and 2. There are additional peaks present, but the exact locations cannot be clearly specified because of the low intensities and/or the large widths of these additional peaks.

Downhole logging data, when available, have also been utilized. Technical problems prevented the use of Leg 128 logging data. A representative subset of logs has been assembled: the spectral and computed $\mathrm{Th}+\mathrm{K}$ gamma-ray emissions (in API units), the Al yield (in wt\%), the gamma-gamma density (in $\mathrm{g} / \mathrm{cm}^{3}$ ), the velocity (in $\mathrm{km} / \mathrm{s}$ ) calculated from the median sonic traveltime, the electrical resistivity (in ohm-m) from the medium-penetration induction log, the porosity indicator ratio (PIR), and the lithology indicator ratio (LIR). The natural gamma-ray emissions are measured both in total and using spectral windows for U, Th, and K. Typically, an increase in the emission of gamma rays from a formation indicates an increase in the clay content, either due to a change in the lithology or due to a decrease in the porosity and an associated increase in the response from the formation matrix. Similarly, the density, velocity, and resistivity will all increase when the porosity decreases. However, the velocity and resistivity will also increase when the clay content decreases. We thus look at the logs in combination to indicate which circumstance is correct. The elemental yields are determined from the gamma-ray response of the formation to neutron activation (Borehole Research Group, 1988). Each element has a unique emission spectrum, and the relative concentrations may be determined. The PIR is then calculated as the ratio of the $\mathrm{H}$ yield to the $(\mathrm{Si}+\mathrm{Ca})$ yields, and the LIR is the ratio of the $\mathrm{Si}$ yield to the $(\mathrm{Si}+\mathrm{Ca}$ ) yields (Borehole Research Group, 1988). The PIR responds to relative changes in the water content, leading to an increase in the $\mathrm{H}$ yield and a decrease in the $\mathrm{Si}+\mathrm{Ca}$ yield, or vice versa, depending on whether the porosity is decreasing or increasing, respectively. The LIR responds to relative changes in the $\mathrm{Si}$ and $\mathrm{Ca}$ content, and in principle is diagnostic of lithologic changes. The LIR and PIR exhibit similar trends, and only the PIR is shown. Logging data are acquired approximately every $15 \mathrm{~cm}$. The specific techniques and logs are described elsewhere (Borehole Research Group, 1988; Shipboard Scientific Party, 1990b, 1990c). Because the core and logging data can be offset in depth, the logging data have been depth-corrected to account for any discrepancy, using the GRAPE density as the reference profile.

\section{RESULTS AND DISCUSSION \\ Opal-A to Opal-CT Transition}

When we examine the profiles in detail, the physical properties suggest a more gradual, less rapid transition from opal-A to opal-CT. At the Yamato Basin Sites 794 (Fig. 5A) and 797 (Fig. 5B), for 


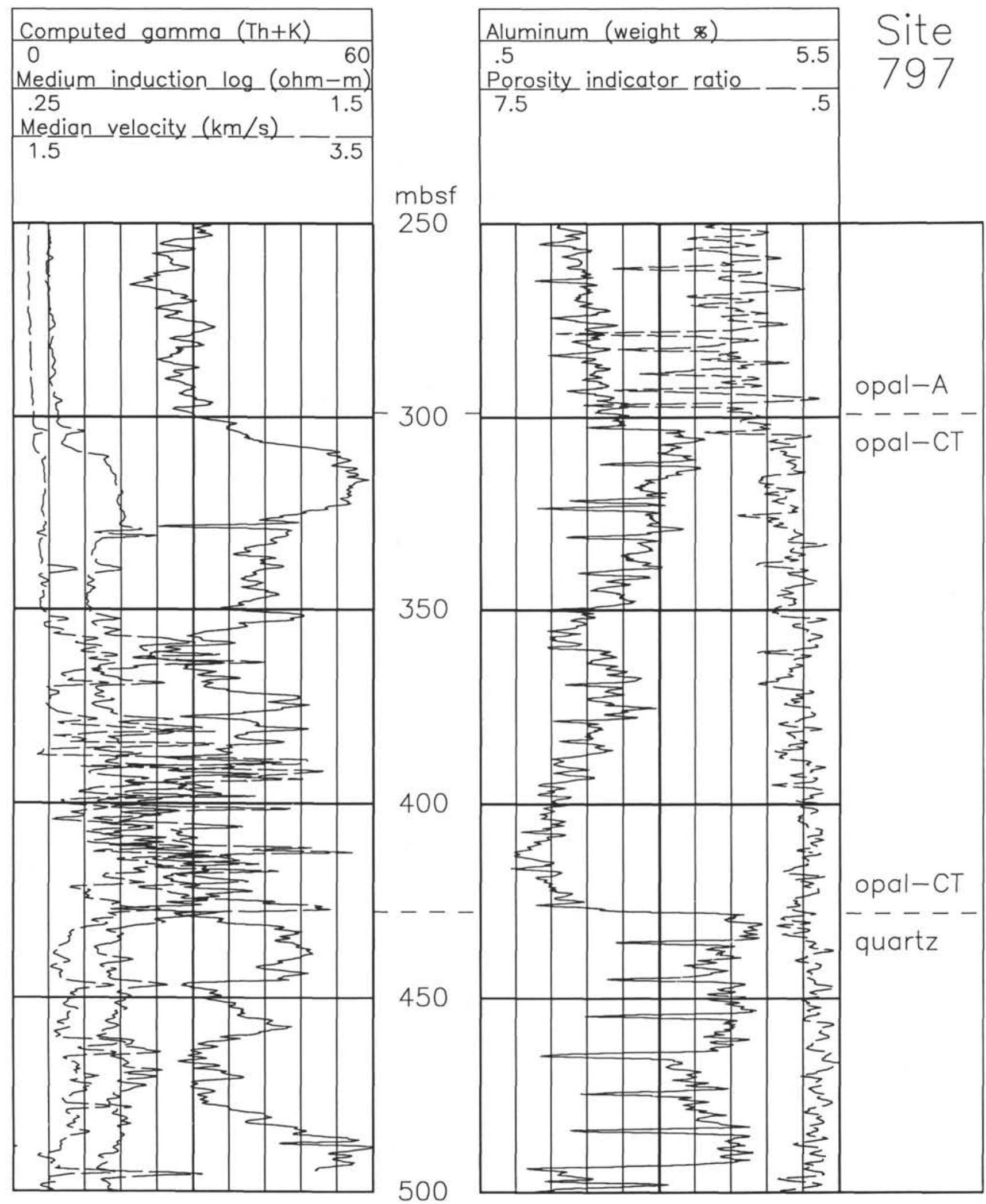

Figure 4. Site 797 smoothed computed Th + K gamma-ray emissions (in American Petroleum Institute, or API, units), medium induction log resistivity (ohm-m), and median velocity $(\mathrm{km} / \mathrm{s})$ on the left, and $\mathrm{Al}$ yield (wt\%) and porosity indicator ratio on the right, in API format. The opal-A/opal-CT and opal-CT/quartz boundaries, as defined by shipboard XRD analyses, are indicated. Note the apparently sharp changes across these boundaries. 
Table 1. X-ray diffraction results, Site 795.

\begin{tabular}{|c|c|c|c|c|c|c|}
\hline \multirow{2}{*}{$\begin{array}{l}\text { Core, section, } \\
\text { interval }(\mathrm{cm})^{\mathrm{a}}\end{array}$} & \multirow{2}{*}{$\begin{array}{l}\text { Depth } \\
\text { (mbsf) }\end{array}$} & \multirow{2}{*}{$\begin{array}{c}\mathrm{d} \\
(\AA)\end{array}$} & \multirow{2}{*}{$\begin{array}{c}2 \theta^{b} \\
\text { (degrees) }\end{array}$} & \multicolumn{2}{|c|}{ Intensity } & \multirow[b]{2}{*}{ Possible source phases $^{d}$} \\
\hline & & & & (cps) & $(\%)^{c}$ & \\
\hline \multicolumn{7}{|l|}{$127-795 \mathrm{~A}-$} \\
\hline \multirow[t]{7}{*}{$34 \mathrm{X}-1,100-102$} & \multirow[t]{7}{*}{308.90} & 7.1 & 12.4 & 82 & 11 & Chlorite, kaolinite, phillipsite \\
\hline & & 4.5 & 19.6 & 203 & 26 & Chlorite, illite, palygorskite? \\
\hline & & 4.3 & 20.7 & 273 & 35 & Quartz ${ }^{*}, \alpha$-tridymite \\
\hline & & 4.1 & 21.8 & 232 & 30 & Opal-CT, phillipsite \\
\hline & & 3.37 & 26.5 & 771 & 100 & Illite, quartz* \\
\hline & & 3.2 & 27.6 & 285 & 37 & Palygorskite?, zeolites \\
\hline & & 2.8 & 31.6 & 261 & 34 & Cristobalite \\
\hline \multirow[t]{9}{*}{$34 \mathrm{X}-3,100-102(\mathrm{SEM})$} & 311.90 & 7.1 & 12.4 & 84 & 10 & Chlorite, halloysite?, kaolinite, phillipsite \\
\hline & & 4.5 & 19.6 & 195 & 24 & Chlorite, halloysite?, illite, palygorskite? \\
\hline & & 4.3 & 20.6 & 251 & 31 & Quartz ${ }^{*}, \alpha$-tridymite \\
\hline & & 4.1 & 21.9 & 199 & 24 & Opal-CT, phillipsite \\
\hline & & 3.8 & 23.5 & 164 & 20 & $\alpha$-tridymite \\
\hline & & 3.6 & 24.1 & 153 & 19 & Halloysite? \\
\hline & & 3.36 & 26.5 & 816 & 100 & Illite, quartz* \\
\hline & & 3.2 & 27.6 & 250 & 31 & Palygorskite?, zeolites \\
\hline & & 2.8 & 31.5 & 172 & 21 & Cristobalite \\
\hline $34 \mathrm{X}-4,100-102$ (SEM) & 313.40 & 7.2 & 12.3 & 105 & 12 & Chlorite, halloysite?, kaolinite, phillipsite \\
\hline & & 4.5 & 19.6 & 227 & 26 & Chlorite, halloysite?, illite, palygorskite? \\
\hline & & 4.3 & 20.7 & 295 & 34 & Quartz*, $\alpha$-tridymite \\
\hline & & 4.1 & 21.8 & 245 & 28 & Opal-CT, phillipsite \\
\hline & & 3.8 & 23.5 & 184 & 21 & $\alpha$-tridymite \\
\hline & & 3.6 & 24.2 & 167 & 19 & Halloysite? \\
\hline & & 3.36 & 26.5 & 868 & 100 & Illite, quartz* \\
\hline & & 3.2 & 27.7 & 281 & 32 & Palygorskite?, zeolites \\
\hline & & 2.8 & 31.6 & 260 & 30 & Cristobalite \\
\hline $34 \mathrm{X}-6,100-102$ (SEM) & 316.40 & 7.2 & 12.3 & 85 & 8 & Chlorite, halloysite?, kaolinite, phillipsite \\
\hline & & 4.5 & 19.7 & 212 & 19 & Chlorite, halloysite?, illite, palygorskite? \\
\hline & & 4.3 & 20.7 & 289 & 26 & Quartz*, $\alpha$-tridymite \\
\hline & & 4.1 & 21.8 & 264 & 24 & Opal-CT, phillipsite \\
\hline & & 3.9 & 22.8 & 152 & 14 & Clinoptilolite?, phillipsite? \\
\hline & & 3.8 & 23.5 & 189 & 17 & $\alpha$-tridymite \\
\hline & & 3.6 & 24.2 & 175 & 16 & Halloysite? \\
\hline & & 3.36 & 26.5 & 1098 & 100 & Illite, quartz* \\
\hline & & 3.2 & 27.7 & 258 & 23 & Palygorskite?, zeolites \\
\hline & & 2.8 & 31.6 & 198 & 18 & Cristobalite \\
\hline $34 \mathrm{X}-7,39-40$ (SEM) & 317.29 & 7.1 & 12.4 & 82 & 12 & Chlorite, halloysite?, kaolinite, phillipsite \\
\hline & & 6.4 & 13.8 & 87 & 13 & Phillipsite? \\
\hline & & 5.0 & 17.8 & 95 & 14 & Illite, phillipsite? \\
\hline & & 4.5 & 19.6 & 204 & 31 & Chlorite, halloysite?, illite \\
\hline & & 4.3 & 20.7 & 305 & 46 & Quartz $*, \alpha$-tridymite \\
\hline & & 4.1 & 21.8 & 255 & 39 & Opal-CT, phillipsite \\
\hline & & 3.8 & 23.4 & 189 & 29 & $\alpha$-tridymite \\
\hline & & 3.6 & 24.2 & 185 & 28 & Halloysite? \\
\hline & & 3.5 & 25.5 & 152 & 23 & Chlorite, illite, kaolinite, zeolites \\
\hline & & 3.36 & 26.5 & 658 & 100 & Illite, quartz* \\
\hline & & 3.2 & 27.7 & 248 & 38 & Palygorskite?, zeolites \\
\hline & & 2.9 & 30.2 & 116 & 18 & Zeolites \\
\hline & & 2.8 & 31.5 & 294 & 45 & Cristobalite \\
\hline $35 \mathrm{X}-1,100-102(\mathrm{SEM})$ & 318.60 & 7.1 & 12.4 & 81 & 11 & Chlorite, halloysite?, kaolinite, phillipsite \\
\hline & & 4.5 & 19.7 & 222 & 30 & Chlorite, halloysite?, illite, palygorskite? \\
\hline & & 4.3 & 20.8 & 295 & 40 & Quartz*, $\alpha$-tridymite \\
\hline & & 4.0 & 22.0 & 235 & 32 & Opal-CT, phillipsite \\
\hline & & 3.9 & 22.8 & 178 & 24 & Clinoptilolite?, phillipsite? \\
\hline & & 3.8 & 23.7 & 186 & 25 & $\alpha$-tridymite \\
\hline & & 3.6 & 24.2 & 189 & 25 & Halloysite? \\
\hline & & 3.36 & 26.5 & 742 & 100 & Illite, quartz* \\
\hline & & 3.2 & 27.8 & 268 & 36 & Palygorskite?, zeolites \\
\hline & & 2.8 & 31.6 & 170 & 23 & Cristobalite \\
\hline $35 \mathrm{X}-3,100-102$ (SEM) & 321.60 & 7.1 & 12.4 & 88 & 8 & Chlorite, halloysite?, kaolinite, phillipsite \\
\hline & & 5.0 & 17.8 & 116 & 11 & nlite \\
\hline & & 4.5 & 19.7 & 225 & 21 & Chlorite, halloysite?, illite, palygorskite? \\
\hline & & 4.3 & 20.8 & 324 & 31 & Quartz ${ }^{*}, \alpha$-tridymite \\
\hline & & 4.1 & 21.9 & 285 & 27 & Opal-CT, phillipsite \\
\hline & & 3.8 & 23.5 & 206 & 20 & $\alpha$-tridymite \\
\hline & & 3.6 & 24.2 & 205 & 20 & Halloysite? \\
\hline & & 3.35 & 26.6 & 1050 & 100 & Illite, quartz* \\
\hline & & 3.2 & 27.8 & 298 & 28 & Palygorskite?, zeolites \\
\hline & & 2.8 & 31.6 & 404 & 38 & Cristobalite \\
\hline
\end{tabular}


Table 1 (continued).

\begin{tabular}{|c|c|c|c|c|c|c|}
\hline \multirow{2}{*}{$\begin{array}{l}\text { Core, section, } \\
\text { interval }(\mathrm{cm})^{\mathrm{a}}\end{array}$} & \multirow{2}{*}{$\begin{array}{l}\text { Depth } \\
\text { (mbsf) }\end{array}$} & \multirow{2}{*}{$\stackrel{d}{d}$} & \multirow{2}{*}{$\begin{array}{c}2 \theta^{b} \\
\text { (degrees) }\end{array}$} & \multicolumn{2}{|c|}{ Intensity } & \multirow[b]{2}{*}{ Possible source phases ${ }^{d}$} \\
\hline & & & & (cps) & $(\%)^{c}$ & \\
\hline \multirow[t]{11}{*}{$35 X-4,100-102$} & 323.10 & 7.1 & 12.4 & 90 & 8 & Chlorite, halloysite?, kaolinite, phillipsite \\
\hline & & 4.5 & 19.7 & 260 & 23 & Chlorite, halloysite?, illite, palygorskite? \\
\hline & & 4.3 & 20.8 & 352 & 32 & Quartz ${ }^{*}, \alpha$-tridymite \\
\hline & & 4.1 & 21.9 & 256 & 24 & Opal-CT, phillipsite \\
\hline & & 3.8 & 23.5 & 176 & 16 & $\alpha$-tridymite \\
\hline & & 3.6 & 24.1 & 188 & 17 & Halloysite? \\
\hline & & 3.5 & 25.2 & 146 & 13 & Chlorite, illite, kaolinite, zeolites \\
\hline & & 3.35 & 26.6 & 1112 & 100 & Illite, quartz* \\
\hline & & 3.2 & 27.9 & 342 & 31 & Palygorskite?, zeolites \\
\hline & & 2.9 & 30.3 & 125 & 11 & Zeolites \\
\hline & & 2.8 & 31.6 & 341 & 31 & Cristobalite \\
\hline \multirow[t]{14}{*}{$35 X-6,100-102$} & 326.10 & 7.1 & 12.5 & 75 & 6 & Chlorite, halloysite?, kaolinite, phillipsite \\
\hline & & 6.4 & 13.7 & 65 & 5 & Phillipsite? \\
\hline & & 4.5 & 19.7 & 227 & 17 & Chlorite, halloysite?, illite, palygorskite? \\
\hline & & 4.3 & 20.8 & 383 & 28 & Quartz*, $\alpha$-tridymite \\
\hline & & 4.1 & 21.9 & 320 & 24 & Opal-CT, phillipsite \\
\hline & & 3.9 & 22.8 & 147 & 11 & Clinoptilolite?, phillipsite? \\
\hline & & 3.8 & 23.5 & 168 & 12 & $\alpha$-tridymite \\
\hline & & 3.6 & 24.2 & 158 & 12 & Halloysite? \\
\hline & & 3.5 & 25.6 & 143 & 11 & Chlorite, illite, kaolinite, zeolites \\
\hline & & 3.35 & 26.6 & 1349 & 100 & Illite, quartz* \\
\hline & & 3.2 & 27.8 & 338 & 25 & Palygorskite?, zeolites \\
\hline & & 3.0 & 29.8 & 117 & 9 & Clinoptilolite? \\
\hline & & 2.9 & 30.3 & 126 & 9 & Zeolites \\
\hline & & 2.8 & 31.6 & 149 & 11 & Cristobalite \\
\hline \multirow[t]{7}{*}{$37 \mathrm{X}-1,99-100$} & 337.89 & 4.5 & 19.7 & 214 & 21 & Chlorite, illite, palygorskite? \\
\hline & & 4.3 & 20.8 & 467 & 46 & Quartz*, $\alpha$-tridymite \\
\hline & & 4.1 & 21.6 & 687 & 68 & Opal-CT \\
\hline & & 3.7 & 24.3 & 151 & 15 & Erionite? \\
\hline & & 3.35 & 26.6 & 1006 & 100 & Illite, quartz* \\
\hline & & 3.2 & 27.8 & 254 & 25 & Palygorskite?, zeolites \\
\hline & & 2.8 & 31.6 & 152 & 15 & Cristobalite \\
\hline \multicolumn{7}{|l|}{$127-795 B-$} \\
\hline \multirow[t]{6}{*}{ 9R-2,111-113 (SEM) } & 445.01 & 4.5 & 19.7 & 215 & 20 & Chlorite, illite, palygorskite? \\
\hline & & 4.3 & 20.8 & 511 & 47 & Quartz, $\alpha$-tridymite \\
\hline & & 4.1 & 21.6 & 1091 & 100 & Opal-CT \\
\hline & & 3.7 & 24.1 & 142 & 13 & Erionite? \\
\hline & & 3.35 & 26.6 & 628 & 58 & Illite, quartz \\
\hline & & 3.2 & 27.9 & 189 & 17 & Palygorskite?, zeolites \\
\hline \multirow[t]{9}{*}{$11 \mathrm{R}-2,81-83$ (SEM) } & 464.01 & 4.5 & 19.6 & 222 & 25 & Chlorite, illite, palygorskite? \\
\hline & & 4.3 & 20.8 & 429 & 49 & Quartz, $\alpha$-tridymite \\
\hline & & 4.1 & 21.7 & 863 & 98 & Opal-CT \\
\hline & & 3.8 & 23.4 & 156 & 18 & $\alpha$-tridymite \\
\hline & & 3.7 & 24.1 & 129 & 15 & Erionite? \\
\hline & & 3.36 & 26.6 & 881 & 100 & Quartz, illite \\
\hline & & 3.2 & 27.8 & 220 & 25 & Palygorskite?, zeolites \\
\hline & & 3.0 & 29.8 & 113 & 13 & Clinoptilolite? \\
\hline & & 2.8 & 31.6 & 114 & 13 & Cristobalite \\
\hline $11 \mathrm{R}-3,120-122$ (SEM) & 465.90 & 4.5 & 19.7 & 253 & 16 & Chlorite, illite, palygorskite? \\
\hline & & 4.3 & 20.8 & 356 & 23 & Quartz, $\alpha$-tridymite \\
\hline & & 4.1 & 21.9 & 232 & 15 & Opal-CT \\
\hline & & 3.8 & 23.5 & 138 & 9 & $\alpha$-tridymite \\
\hline & & 3.7 & 24.3 & 119 & 8 & Erionite? \\
\hline & & 3.36 & 26.5 & 1558 & 100 & Illite, quartz \\
\hline & & 3.2 & 27.8 & 250 & 16 & Palygorskite?, zeolites \\
\hline & & 3.0 & 29.7 & 107 & 7 & Clinoptilolite? \\
\hline $12 \mathrm{R}-3,96-98$ (SEM) & 475.36 & 4.5 & 19.7 & 250 & 16 & Chlorite, illite, palygorskite? \\
\hline & & 4.3 & 20.7 & 342 & 22 & Quartz, $\alpha$-tridymite \\
\hline & & 4.1 & 21.9 & 143 & 9 & Opal-CT \\
\hline & & 3.9 & 22.5 & 93 & 6 & Clinoptilolite? \\
\hline & & 3.8 & 23.5 & 122 & 8 & $\alpha$-tridymite \\
\hline & & 3.7 & 24.2 & 114 & 7 & Erionite? \\
\hline & & 3.5 & 25.5 & 133 & 8 & Chlorite, illite, kaolinite?, zeolites \\
\hline & & 3.36 & 26.5 & 1586 & 100 & Illite, quartz \\
\hline & & 3.2 & 27.8 & 227 & 14 & Palygorskite?, zeolites \\
\hline & & 3.0 & 29.7 & 104 & 7 & Clinoptilolite? \\
\hline
\end{tabular}


Table 1 (continued).

\begin{tabular}{|c|c|c|c|c|c|c|}
\hline \multirow{2}{*}{$\begin{array}{l}\text { Core, section, } \\
\text { interval }(\mathrm{cm})^{\mathrm{a}}\end{array}$} & \multirow{2}{*}{$\begin{array}{l}\text { Depth } \\
\text { (mbsf) }\end{array}$} & \multirow{2}{*}{$\stackrel{\text { d }}{(\AA)}$} & \multirow{2}{*}{$\begin{array}{c}2 \theta^{\mathrm{b}} \\
\text { (degrees) }\end{array}$} & \multicolumn{2}{|c|}{ Intensity } & \multirow[b]{2}{*}{ Possible source phases ${ }^{d}$} \\
\hline & & & & (cps) & $(\%)^{\mathrm{c}}$ & \\
\hline \multirow[t]{9}{*}{$13 R-3,63-65$} & 484.64 & 7.2 & 12.3 & 78 & 4 & Chlorite, halloysite?, kaolinite, phillipsite \\
\hline & & 4.5 & 19.7 & 260 & 13 & Chlorite, halloysite?, illite, palygorskite? \\
\hline & & 4.3 & 20.8 & 429 & 22 & Quartz, $\alpha$-tridymite \\
\hline & & 4.1 & 22.0 & 146 & 7 & Opal-CT, phillipsite \\
\hline & & 3.8 & 23.5 & 144 & 7 & $\alpha$-tridymite \\
\hline & & 3.6 & 24.2 & 127 & 6 & Halloysite? \\
\hline & & 3.36 & 26.5 & 1983 & 100 & Illite, quartz \\
\hline & & 3.2 & 27.9 & 242 & 12 & Palygorskite?, zeolites \\
\hline & & 3.0 & 29.7 & 119 & 6 & Clinoptilolite? \\
\hline
\end{tabular}

Notes: The XRD analyses were carried out on bulk samples, without any treatment or separation, in the Department of Chemistry of the University of Waterloo. $\mathrm{A} \mathrm{Cu}_{\mathrm{K} \alpha}$ source was used in a Siemens D500 diffractometer at a scan rate of $0.015 \%$, from $12^{\circ}$ to $32^{\circ}(2 \theta)$.

a "SEM" after the sample number indicates that a portion of the sample was also used for scanning electron microscopy work.

${ }^{\mathrm{b}}$ The peaks are arranged in order of their $2 \theta$ values.

'Relative peak height is expressed as a percentage of the sample maximum peak intensity.

d "Opal-CT" indicates undifferentiated cristobalite and tridymite. "Zeolites" indicates undifferentiated zeolite phases, though clinoptilolite and phillipsite are the most common zeolites in marine sediment, and analcime and laumontite are not uncommon. The height and width of the peaks frequently prevent the resolution of specific phases. For Sections 127-795A-34X-1 through - 37X-1, the quartz is detrital in origin, and is flagged with an asterisk $(*)$. References: Finney et al. (1975), JCPDS (1978), Chen et al. (1978), Hawkins et al. (1978), Gottardi and Galli (1985), and Roberts et al. (1990).

example, the transition zone appears to be broad and smooth. In contrast, the changes at Sites 795 (Fig. 6A) and 799 (Fig. 6B) appear to be abrupt, although sampling problems associated with poor core recovery may play a role. The changes observed in the Site 799 profiles bracket the opal-A/opal-CT boundary as defined by shipboard analyses. Finally, the opal-A to opal-CT transition is barely noticeable at the rise Sites 796 and 798 (Fig. 7), located on the Okushiri and Oki ridges, respectively. However, the physical properties do go through distinct changes above the opal-A/opal-CT boundary, as defined by shipboard analyses.

The XRD results also suggest a gentler, nonuniform transition from opal-A to opal-CT. The XRD results are shown for a representative set of samples across the opal-A/opal-CT transition for Hole 795A (Fig. 8), and for Hole 797B (Fig. 9). Samples from Sections 127-795A-34X-3 to $-35 \mathrm{X}-6$, and from Sections $127-797 \mathrm{~B}-31 \mathrm{X}-3$ to $-33 \mathrm{X}-1$ yield similar results, and the XRD scans are shown for only a few samples to simplify the presentation. There are indications that incipient but not significant opal-CT is present well above the apparent opal-A to opal-CT boundary, both in the set of low-intensity peaks located at $2 \theta$ angles of $21.9^{\circ}(4.1 \AA), 23.5^{\circ}(3.8 \AA)$, and $31.6^{\circ}(2.8 \AA)$ and in the SEM plates. Frustule fragments corroded by dissolution are present at least $15 \mathrm{~m}$ above the diagenetic boundary (Pl. 1). At the same time, samples with little or no indication of dissolution or of the presence of opal-CT (PI. 2) are present stratigraphically below samples that have clear signs of dissolution and/or common opal-CT. The samples are not outwardly different in lithology; the XRD results are consistent above the opal-A/opal-CT boundary. The increase in the intensity of the opal-CT peak in Sample 127-795B-37X-1, 99-100 cm, is consistent with the sharp changes observed in the physical properties, but opal-CT is present above the boundary, and the physical properties are highly variable below the boundary. These observations suggest that the diagenetic process is non-uniform and sometimes gradational.

Below the opal-A/opal-CT boundary at Site 795, opal-CT is ubiquitous, and other mineral phases, while encountered, are not present in substantial quantities. At Site 797, in contrast, a number of mineral phases are common. The transformation from opal-A to opal-CT at Site 797 is not as obvious in the XRD results either; even for Sample 127-797B-33X-3, 100-102 cm, which is clearly below the transition zone, the opal-CT peaks are not high in intensity. The higher clay content at Site 797 (Shipboard Scientific Party, 1990h), in addition to diluting the silica component, may act to retard the diagenetic reaction (Kastner et al., 1977; Kastner and Gieskes, 1983). Representative XRD peaks are present for detrital quartz, for clay minerals such as chlorite, illite, palygorskite, kaolinite, and halloysite (a member of the kaolin group), and for zeolites such as clinoptilolite (Tables 1 and 2). Clinoptilolite, other zeolites, and clay minerals are also noted in the SEM photographs (Pl. 3).

Zeolites, particularly clinoptilolite, are natural byproducts of the opal-A to opal-CT reaction in the presence of the clay minerals illite and smectite (Stonecipher, 1978; Kastner, 1979, 1981). Zeolites are an important phase in silica diagenesis in marine sediments (Kastner, 1979, 1981), and clinoptilolite is one of the more common forms. The highest intensity clinoptilolite peaks (based on Chen et al., 1978, and Gottardi and Galli, 1985) are observed for Sample 127-797B-33X-3, 100-102 cm (Fig. 9 and Table 2). Phillipsite and analcime (or analcite) are common, and laumontite has also been found in marine sediments (Gottardi and Galli, 1985; Kastner, 1979, 1981). Erionite and mordenite are sedimentary zeolites, but their presence in marine formations has not been previously noted (Gottardi and Galli, 1985).

The opal-A/opal-CT boundary appears to be poorly defined by the XRD results, which indicate the presence of opal-CT above the boundary. At Site 797, we do not see an increase in the intensity of the opal-CT peaks below the boundary. We therefore turn to the physical properties to define the position and thickness of the diagenetic transition zone. We expect the largest changes to occur where the greatest change from opal-A to opal-CT occurs, since there is a decrease in porosity associated with the dissolution of the amorphous, open-cellular structure of the diatoms and the precipitation of the opal-CT. In many instances, the largest changes in the physical properties occur some meters above or below the opal-A/opal-CT boundary as defined by shipboard analyses. At Site 797 (Fig. 10), for example, the GRAPE density, Al yield, and computed Th + K gamma-ray emission begin to decrease $5 \mathrm{~m}$ above the boundary, and the largest gradients occur approximately $4 \mathrm{~m}$ below. This suggests that the opal-A/opal-CT boundary at Site 797 should in fact be placed $4 \mathrm{~m}$ below the position assigned on the basis of the shipboard analyses, at $303 \mathrm{mbsf}$, just below the base of Unit III (Shipboard Scientific Party, 1990h).

We may follow a similar process for each of the sites. The largest gradients in the Site 794 GRAPE density and logging properties occur very near the boundary as defined by the shipboard analyses, $293.5 \mathrm{mbsf}$ (Shipboard Scientific Party, 1990e). The largest changes in the Site 795 
Table 2. X-ray diffraction results, Site 797.

\begin{tabular}{|c|c|c|c|c|c|c|}
\hline \multirow{2}{*}{$\begin{array}{l}\text { Core, section, } \\
\text { interval }(\mathrm{cm})^{\mathrm{a}}\end{array}$} & \multirow{2}{*}{$\begin{array}{l}\text { Depth } \\
\text { (mbsf) }\end{array}$} & \multirow{2}{*}{$\stackrel{d}{d}$} & \multirow{2}{*}{$\begin{array}{c}2 \theta^{b} \\
\text { (degrees) }\end{array}$} & \multicolumn{2}{|c|}{ Intensity } & \multirow[b]{2}{*}{ Possible source phases $^{d}$} \\
\hline & & & & (cps) & $(\%)^{c}$ & \\
\hline \multicolumn{7}{|l|}{ 127-797B- } \\
\hline \multirow[t]{15}{*}{$31 X-1,99-101$} & 283.90 & 10.1 & 8.7 & 107 & 13 & Halloysite?, illite, palygorskite \\
\hline & & 7.1 & 12.4 & 75 & 9 & Chlorite, halloysite?, kaolinite, phillipsite \\
\hline & & 6.4 & 13.7 & 73 & 9 & Erionite?, phillipsite? \\
\hline & & 4.5 & 19.7 & 236 & 29 & Chlorite, halloysite?, illite, palygorskite \\
\hline & & 4.3 & 20.8 & 263 & 32 & Erionite?, quartz ${ }^{*}, \alpha$-tridymite \\
\hline & & 4.1 & 21.9 & 177 & 22 & Opal-CT, phillipsite \\
\hline & & 3.9 & 22.7 & 132 & 16 & Clinoptilolite?, phillipsite \\
\hline & & 3.8 & 23.5 & 160 & 19 & $\alpha$-tridymite \\
\hline & & 3.7 & 23.8 & 191 & 23 & Erionite?, laumontite? \\
\hline & & 3.6 & 24.2 & 158 & 19 & Erionite?, halloysite? \\
\hline & & 3.35 & 26.6 & 821 & 100 & Erionite?, illite, quartz ${ }^{*}$ \\
\hline & & 3.2 & 27.7 & 241 & 29 & Palygorskite, zeolites \\
\hline & & 3.1 & 28.4 & 128 & 16 & Saponite?, zeolites \\
\hline & & 3.0 & 29.8 & 116 & 14 & Clinoptilolite? \\
\hline & & 2.8 & 31.6 & 331 & 40 & Cristobalite, erionite? \\
\hline $31 X-2,98-100$ & 284.70 & 10.1 & 8.7 & 118 & 14 & Halloysite?, illite, palygorskite \\
\hline & & 7.1 & 12.4 & 88 & 10 & Chlorite, halloysite?, kaolinite, phillipsite \\
\hline & & 4.5 & 19.7 & 241 & 28 & Chlorite, halloysite?, illite, palygorskite \\
\hline & & 4.3 & 20.8 & 303 & 36 & Quartz*, $\alpha$-tridymite \\
\hline & & 4.1 & 21.9 & 233 & 27 & Opal-CT, phillipsite \\
\hline & & 3.9 & 22.8 & 168 & 20 & Clinoptilolite?, phillipsite \\
\hline & & 3.8 & 23.5 & 211 & 25 & $\alpha$-tridymite \\
\hline & & 3.6 & 24.1 & 167 & 20 & Halloysite? \\
\hline & & 3.35 & 26.6 & 851 & 100 & Illite, quartz* \\
\hline & & 3.2 & 27.8 & 292 & 34 & Palygorskite, zeolites \\
\hline & & 2.9 & 30.3 & 162 & 19 & Zeolites \\
\hline & & 2.8 & 31.6 & 389 & 46 & Cristobalite \\
\hline $31 X-3,98-100($ SEM) & 286.20 & 7.1 & 12.4 & 75 & 9 & Chlorite, halloysite?, kaolinite, phillipsite \\
\hline & & 4.5 & 19.8 & 253 & 31 & Chlorite, halloysite?, illite \\
\hline & & 4.3 & 20.8 & 313 & 38 & Quartz*, $\alpha$-tridymite \\
\hline & & 4.1 & 21.9 & 247 & 30 & Opal-CT, phillipsite \\
\hline & & 3.9 & 22.7 & 154 & 19 & Clinoptilolite?, phillipsite \\
\hline & & 3.8 & 23.5 & 196 & 24 & $\alpha$-tridymite \\
\hline & & 3.6 & 24.4 & 228 & 28 & Halloysite? \\
\hline & & 3.35 & 26.6 & 829 & 100 & Illite, quartz* \\
\hline & & 3.2 & 27.8 & 270 & 33 & Zeolites \\
\hline & & 2.8 & 31.6 & 351 & 42 & Cristobalite \\
\hline $31 X-4,97-99$ & 287.70 & 7.1 & 12.4 & 92 & 11 & Chlorite, halloysite?, kaolinite, phillipsite \\
\hline & & 4.5 & 19.6 & 258 & 31 & Chlorite, halloysite?, illite \\
\hline & & 4.3 & 20.8 & 268 & 33 & Quartz, $\alpha$-tridymite \\
\hline & & 4.1 & 22.0 & 199 & 24 & Opal-CT, phillipsite \\
\hline & & 3.9 & 22.7 & 189 & 23 & Clinoptilolite?, phillipsite \\
\hline & & 3.8 & 23.5 & 163 & 20 & $\alpha$-tridymite \\
\hline & & 3.6 & 24.2 & 159 & 19 & Halloysite? \\
\hline & & 3.35 & 26.6 & 820 & 100 & Quartz*, illite \\
\hline & & 3.3 & 27.4 & 185 & 23 & Zeolites \\
\hline & & 3.2 & 27.9 & 223 & 27 & Zeolites \\
\hline & & $3.1(5)$ & 28.3 & 140 & 17 & Cristobalite?, zeolites \\
\hline & & $3.1(1)$ & 28.6 & 121 & 15 & Saponite?, zeolites \\
\hline & & 2.8 & 31.6 & 396 & 48 & Cristobalite \\
\hline $31 X-5,96-98$ (SEM) & 289.20 & 7.2 & 12.3 & 64 & 10 & Chlorite, halloysite?, kaolinite, phillipsite \\
\hline & & 4.5 & 19.7 & 161 & 24 & Chlorite, halloysite?, illite \\
\hline & & 4.3 & 20.8 & 215 & 33 & Quartz, $\alpha$-tridymite \\
\hline & & 4.1 & 21.9 & 128 & 19 & Opal-CT, phillipsite \\
\hline & & 3.9 & 22.8 & 90 & 14 & Clinoptilolite?, phillipsite \\
\hline & & 3.8 & 23.6 & 289 & 44 & $\alpha$-tridymite \\
\hline & & 3.6 & 24.3 & 101 & 15 & Halloysite? \\
\hline & & 3.35 & 26.6 & 658 & 100 & Quartz*, illite \\
\hline & & 3.2 & 27.8 & 367 & 56 & Zeolites \\
\hline & & $3.1(5)$ & 28.4 & 117 & 18 & Cristobalite?, zeolites \\
\hline & & 3.0 & 29.3 & 96 & 15 & Clinoptilolite? \\
\hline & & 2.9 & 30.6 & 176 & 27 & Zeolites \\
\hline & & 2.8 & 31.6 & 227 & 34 & Cristobalite \\
\hline $31 X-6,95-97$ & 290.70 & 7.1 & 12.4 & 86 & 11 & Chlorite, halloysite?, kaolinite, phillipsite \\
\hline & & 5.0 & 17.6 & 77 & 10 & Illite, phillipsite? \\
\hline & & 4.5 & 19.7 & 235 & 29 & Chlorite, halloysite?, illite \\
\hline & & 4.3 & 20.7 & 249 & 31 & Quartz*, $\alpha$-tridymite \\
\hline & & 4.1 & 21.8 & 155 & 19 & Opal-CT, phillipsite \\
\hline & & 3.9 & 22.7 & 118 & 15 & Clinoptilolite?, phillipsite \\
\hline & & 3.8 & 23.5 & 135 & 17 & $\alpha$-tridymite \\
\hline & & 3.6 & 24.2 & 134 & 17 & Halloysite? \\
\hline & & 3.5 & 25.2 & 119 & 15 & Chlorite, illite, kaolinite, zeolites \\
\hline
\end{tabular}


Table 2 (continued).

\begin{tabular}{|c|c|c|c|c|c|c|}
\hline \multirow{2}{*}{$\begin{array}{l}\text { Core, section, } \\
\text { interval }(\mathrm{cm})^{\mathrm{a}}\end{array}$} & \multirow{2}{*}{$\begin{array}{l}\text { Depth } \\
\text { (mbsf) }\end{array}$} & \multirow{2}{*}{$\stackrel{d}{d}$} & \multirow{2}{*}{$\begin{array}{c}2 \theta^{b} \\
\text { (degrees) }\end{array}$} & \multicolumn{2}{|c|}{ Intensity } & \multirow[b]{2}{*}{ Possible source phases ${ }^{d}$} \\
\hline & & & & (cps) & $(\%)^{c}$ & \\
\hline \multirow{16}{*}{$31 X-7,30-32$ (SEM) } & \multirow{9}{*}{291.50} & 3.36 & 26.5 & 804 & 100 & Quartz*, illite \\
\hline & & 3.2 & 27.7 & 211 & 26 & Zeolites \\
\hline & & 3.0 & 29.7 & 113 & 14 & Clinoptilolite? \\
\hline & & 2.8 & 31.6 & 239 & 30 & Cristobalite \\
\hline & & 7.1 & 12.4 & 82 & 10 & Chlorite, halloysite?, kaolinite, phillipsite \\
\hline & & 4.5 & 19.7 & 244 & 30 & Chlorite, halloysite?, illite \\
\hline & & 4.3 & 20.8 & 252 & 31 & Quartz ${ }^{*}, \alpha$-tridymite \\
\hline & & 4.1 & 21.9 & 178 & 22 & Opal-CT, phillipsite \\
\hline & & 3.9 & 22.7 & 129 & 16 & Clinoptilolite?, phillipsite \\
\hline & & 3.8 & 23.4 & 137 & 17 & $\alpha$-tridymite \\
\hline & & 3.6 & 24.1 & 132 & 16 & Halloysite? \\
\hline & & 3.5 & 25.3 & 124 & 15 & Chlorite, illite, kaolinite, zeolites \\
\hline & & 3.36 & 26.5 & 820 & 100 & Quartz*, illite \\
\hline & & 3.2 & 27.7 & 215 & 26 & Zeolites \\
\hline & & 3.0 & 29.7 & 107 & 13 & Clinoptilolite? \\
\hline & & 2.8 & 31.6 & 248 & 30 & Cristobalite \\
\hline \multirow[t]{11}{*}{$32 \mathrm{X}-1,100-102$ (SEM) } & 292.90 & 9.0 & 9.8 & 80 & 11 & Clinoptilolite \\
\hline & & 7.2 & 12.3 & 69 & 10 & Chlorite, halloysite?, kaolinite, phillipsite \\
\hline & & 4.5 & 19.7 & 245 & 34 & Chlorite, halloysite?, illite \\
\hline & & 4.3 & 20.7 & 249 & 35 & Quartz*, $\alpha$-tridymite \\
\hline & & 4.1 & 21.8 & 186 & 26 & Opal-CT, phillipsite \\
\hline & & 3.9 & 22.7 & 123 & 17 & Clinoptilolite, phillipsite \\
\hline & & 3.8 & 23.5 & 175 & 24 & $\alpha$-tridymite \\
\hline & & 3.6 & 24.2 & 136 & 19 & Halloysite? \\
\hline & & 3.36 & 26.5 & 717 & 100 & Quartz*, illite \\
\hline & & 3.2 & 27.9 & 258 & 36 & Zeolites \\
\hline & & 2.8 & 31.6 & 362 & 50 & Cristobalite \\
\hline $32 \mathrm{X}-2,98-100(\mathrm{SEM})$ & 294.40 & 7.1 & 12.4 & 90 & 11 & Chlorite, halloysite?, kaolinite, phillipsite \\
\hline & & 4.5 & 19.7 & 264 & 33 & Chlorite, halloysite?, illite \\
\hline & & 4.3 & 20.8 & 248 & 31 & Quartz*, $\alpha$-tridymite \\
\hline & & 4.1 & 21.9 & 202 & 25 & Opal-CT, phillipsite \\
\hline & & 3.8 & 23.5 & 169 & 21 & $\alpha$-tridymite \\
\hline & & 3.6 & 24.3 & 161 & 20 & Halloysite? \\
\hline & & 3.35 & 26.6 & 793 & 100 & Quartz*, illite \\
\hline & & 3.2 & 27.8 & 282 & 36 & Zeolites \\
\hline & & 3.0 & 29.8 & 114 & 14 & Clinoptilolite? \\
\hline & & 2.8 & 31.6 & 298 & 38 & Cristobalite \\
\hline $32 \mathrm{X}-3,99-100$ (SEM) & 295.90 & 10.1 & 8.7 & 125 & 15 & Halloysite?, illite, palygorskite \\
\hline & & 7.1 & 12.4 & 90 & 10 & Chlorite, halloysite?, kaolinite, phillipsite \\
\hline & & 4.5 & 19.8 & 268 & 31 & Chlorite, halloysite?, illite, palygorskite \\
\hline & & 4.3 & 20.8 & 256 & 30 & Quartz $*, \alpha$-tridymite \\
\hline & & 4.1 & 22.0 & 187 & 22 & Opal-CT, phillipsite \\
\hline & & 3.9 & 22.7 & 129 & 15 & Clinoptilolite?, phillipsite \\
\hline & & 3.8 & 23.5 & 143 & 17 & $\alpha$-tridymite \\
\hline & & 3.6 & 24.2 & 128 & 15 & Halloysite? \\
\hline & & 3.5 & 25.5 & 133 & 15 & Chlorite, illite, kaolinite, zeolites \\
\hline & & 3.35 & 26.6 & 861 & 100 & Quartz*, illite \\
\hline & & 3.2 & 27.8 & 271 & 31 & Palygorskite, zeolites \\
\hline & & $3.1(4)$ & 28.4 & 132 & 15 & Cristobalite?, zeolites \\
\hline & & $3.1(1)$ & 28.7 & 116 & 13 & Saponite?, zeolites \\
\hline & & 3.0 & 29.8 & 118 & 14 & Clinoptilolite? \\
\hline & & 2.9 & 30.3 & 113 & 13 & Zeolites \\
\hline & & 2.8 & 31.6 & 385 & 45 & Cristobalite \\
\hline $127-797 \mathrm{~B}-$ & & & & & & \\
\hline $32 \mathrm{X}-4,99-101$ & 297.40 & 7.1 & 12.4 & 88 & 11 & Chlorite, halloysite?, kaolinite, phillipsite \\
\hline & & 5.0 & 17.5 & 70 & 9 & Illite, phillipsite? \\
\hline & & 4.5 & 19.8 & 240 & 29 & Chlorite, halloysite?, illite \\
\hline & & 4.3 & 20.8 & 263 & 32 & Quartz $*, \alpha$-tridymite \\
\hline & & 4.1 & 21.9 & 203 & 25 & Opal-CT, phillipsite \\
\hline & & 3.9 & 22.8 & 116 & 14 & Clinoptilolite?, phillipsite \\
\hline & & 3.8 & 23,5 & 141 & 17 & $\alpha$-tridymite \\
\hline & & 3.6 & 24.2 & 128 & 16 & Halloysite? \\
\hline & & 3.5 & 25.3 & 124 & 15 & Chlorite, illite, kaolinite, zeolites \\
\hline & & 3.35 & 26.6 & 818 & 100 & Quartz*, illite \\
\hline & & 3.2 & 27.9 & 237 & 29 & Zeolites \\
\hline & & 3.1 & 28.3 & 134 & 16 & Cristobalite?, saponite?, zeolites \\
\hline & & 3.0 & 29.8 & 107 & 13 & Clinoptilolite? \\
\hline & & 2.8 & 31.7 & 188 & 23 & Cristobalite \\
\hline $32 X-5,99-101$ & 298.90 & 9.0 & 9.8 & 99 & 11 & Clinoptilolite \\
\hline & & 8.0 & 11.1 & 75 & 8 & Clinoptilolite \\
\hline & & 7.1 & 12.4 & 74 & 8 & Chlorite, kaolinite, phillipsite \\
\hline
\end{tabular}


Table 2 (continued).

\begin{tabular}{|c|c|c|c|c|c|c|}
\hline \multirow{2}{*}{$\begin{array}{l}\text { Core, section, } \\
\text { interval }(\mathrm{cm})^{\mathrm{a}}\end{array}$} & \multirow{2}{*}{$\begin{array}{l}\text { Depth } \\
\text { (mbsf) }\end{array}$} & \multirow{2}{*}{$\stackrel{\mathrm{d}}{(\AA)}$} & \multirow{2}{*}{$\begin{array}{c}2 \theta^{b} \\
\text { (degrees) }\end{array}$} & \multicolumn{2}{|c|}{ Intensity } & \multirow[b]{2}{*}{ Possible source phases ${ }^{d}$} \\
\hline & & & & (cps) & $(\%)^{c}$ & \\
\hline & & 4.5 & 19.7 & 261 & 28 & Chlorite, illite \\
\hline & & 4.3 & 20.8 & 295 & 32 & Quartz*, $\alpha$-tridymite \\
\hline & & 4.1 & 21.9 & 250 & 27 & Opal-CT, phillipsite \\
\hline & & 3.8 & 23.6 & 170 & 18 & $\alpha$-tridymite \\
\hline & & 3.35 & 26.6 & 925 & 100 & Quartz*, illite \\
\hline & & 3.2 & 27.7 & 766 & 83 & Zeolites \\
\hline & & 3.0 & 29.9 & 123 & 13 & Clinoptilolite \\
\hline & & 2.8 & 31.6 & 260 & 28 & Cristobalite \\
\hline \multirow[t]{12}{*}{$32 X-6,98-100$} & 300.40 & 10.3 & 8.6 & 139 & 14 & Halloysite?, illite, palygorskite \\
\hline & & 7.1 & 12.4 & 80 & 8 & Chlorite, halloysite?, kaolinite, phillipsite \\
\hline & & 4.5 & 19.7 & 246 & 26 & Chlorite, halloysite?, illite, palygorskite \\
\hline & & 4.3 & 20.8 & 320 & 33 & Quartz*, $\alpha$-tridymite \\
\hline & & 4.1 & 22.0 & 232 & 24 & Opal-CT, phillipsite \\
\hline & & 3.8 & 23.5 & 155 & 16 & $\alpha$-tridymite \\
\hline & & 3.6 & 24.1 & 137 & 14 & Halloysite? \\
\hline & & 3.5 & 25.2 & 134 & 14 & Chlorite, illite, kaolinite, zeolites \\
\hline & & 3.35 & 26.6 & 962 & 100 & Quartz*, illite \\
\hline & & 3.2 & 27.8 & 253 & 26 & Palygorskite, zeolites \\
\hline & & 3.0 & 29.9 & 126 & 13 & Clinoptilolite? \\
\hline & & 2.8 & 31.6 & 173 & 18 & Cristobalite \\
\hline \multirow[t]{16}{*}{$33 \mathrm{X}-1,98-100$} & 302.50 & 10.1 & 8.8 & 131 & 13 & Halloysite?, illite, palygorskite \\
\hline & & 9.0 & 9.8 & 83 & 8 & Clinoptilolite, mordenite? \\
\hline & & 7.2 & 12.4 & 78 & 8 & Chlorite, halloysite?, kaolinite, phillipsite \\
\hline & & 5.0 & 17.6 & 76 & 8 & Illite, phillipsite? \\
\hline & & 4.5 & 19.8 & 261 & 27 & Chlorite, halloysite?, illite, palygorskite \\
\hline & & 4.3 & 20.8 & 280 & 28 & Quartz*, $\alpha$-tridymite \\
\hline & & $4.0(4)$ & 22.0 & 203 & 21 & Opal-CT, phillipsite? \\
\hline & & $4.0(0)$ & 22.4 & 157 & 16 & Clinoptilolite, phillipsite \\
\hline & & 3.9 & 22.8 & 151 & 15 & Clinoptilolite, phillipsite \\
\hline & & 3.8 & 23.6 & 148 & 15 & $\alpha$-tridymite \\
\hline & & 3.6 & 24.2 & 141 & 14 & Halloysite? \\
\hline & & 3.5 & 25.4 & 127 & 13 & Chlorite, illite, kaolinite, zeolites \\
\hline & & 3.35 & 26.6 & 984 & 100 & Quartz*, illite \\
\hline & & 3.2 & 27.7 & 947 & 96 & Palygorskite, zeolites \\
\hline & & 3.0 & 29.8 & 118 & 12 & Clinoptilolite \\
\hline & & 2.8 & 31.7 & 209 & 21 & Cristobalite \\
\hline $33 X-3,100-102$ & 305.50 & 10.1 & 8.8 & 111 & 10 & Palygorskite, illite \\
\hline & & 9.0 & 9.9 & 139 & 13 & Clinoptilolite \\
\hline & & 8.0 & 11.1 & 81 & 7 & Clinoptilolite \\
\hline & & 5.1 & 17.2 & 83 & 7 & Illite \\
\hline & & 4.5 & 19.7 & 232 & 21 & Chlorite, illite, palygorskite \\
\hline & & 4.3 & 20.8 & 273 & 25 & Quartz ${ }^{*}, \alpha$-tridymite \\
\hline & & 4.1 & 21.9 & 179 & 16 & Opal-CT \\
\hline & & 4.0 & 22.3 & 205 & 19 & Clinoptilolite \\
\hline & & 3.9 & 22.8 & 166 & 15 & Clinoptilolite \\
\hline & & 3.8 & 23.6 & 146 & 13 & $\alpha$-tridymite \\
\hline & & 3.7 & 24.2 & 137 & 12 & Erionite? \\
\hline & & 3.35 & 26.6 & 1108 & 100 & Quartz*, illite \\
\hline & & 3.2 & 27.9 & 286 & 26 & Palygorskite, zeolites \\
\hline & & 3.0 & 29.9 & 158 & 14 & Clinoptilolite \\
\hline & & 2.9 & 30.3 & 136 & 12 & Zeolites \\
\hline & & 2.8 & 31.5 & 130 & 12 & Cristobalite \\
\hline $44 \mathrm{X}-1,29-31$ (SEM) & 407.59 & 10.3 & 8.6 & 108 & 9 & Illite, palygorskite \\
\hline & & 9.0 & 9.8 & 103 & 8 & Clinoptilolite \\
\hline & & 4.5 & 19.8 & 208 & 17 & Chlorite, illite, palygorskite \\
\hline & & 4.3 & 20.5 & 588 & 47 & $\alpha$-tridymite, quartz \\
\hline & & 4.1 & 21.7 & 1241 & 100 & Opal-CT \\
\hline & & 3.35 & 26.6 & 395 & 32 & Quartz, illite \\
\hline & & 3.2 & 27.7 & 177 & 14 & Palygorskite, zeolites \\
\hline & & 3.1 & 28.5 & 145 & 12 & Cristobalite? \\
\hline & & 3.0 & 29.9 & 136 & 11 & Clinoptilolite \\
\hline $46 \mathrm{X}-1,40-42$ (SEM) & 427.00 & 9.0 & 9.8 & 86 & 9 & Clinoptilolite \\
\hline & & 4.5 & 19.7 & 194 & 20 & Chlorite, illite \\
\hline & & 4.3 & 20.6 & 472 & 48 & $\alpha$-tridymite, quartz \\
\hline & & 4.1 & 21.7 & 981 & 100 & Opal-CT \\
\hline & & 3.8 & 23.5 & 171 & 17 & $\alpha$-tridymite \\
\hline & & 3.35 & 26.6 & 565 & 58 & Illite, quartz \\
\hline & & 3.2 & 27.7 & 157 & 16 & Zeolites \\
\hline & & 3.1 & 28.4 & 136 & 14 & Crisotobalite?, saponite?, zeolites \\
\hline & & 3.0 & 29.8 & 113 & 12 & Clinoptilolite \\
\hline & & 2.8 & 31.7 & 118 & 12 & Cristobalite \\
\hline $47 \mathrm{X}-1,107-109$ (SEM) & 437.27 & 5.0 & 17.7 & 63 & 2 & Illite \\
\hline & & 4.5 & 19.7 & 254 & 10 & Chlorite, illite \\
\hline
\end{tabular}


Table 2 (continued).

\begin{tabular}{|c|c|c|c|c|c|c|}
\hline \multirow[b]{2}{*}{$\begin{array}{l}\text { Core, section, } \\
\text { interval }(\mathrm{cm})^{\mathrm{a}}\end{array}$} & \multirow[b]{2}{*}{$\begin{array}{l}\text { Depth } \\
\text { (mbsf) }\end{array}$} & \multirow[b]{2}{*}{$\begin{array}{c}\mathrm{d} \\
(\AA \AA \AA)\end{array}$} & \multirow{2}{*}{$\begin{array}{c}2 \theta^{\mathrm{b}} \\
\text { (degrees) }\end{array}$} & \multicolumn{2}{|c|}{ Intensity } & \multirow[b]{2}{*}{ Possible source phases ${ }^{d}$} \\
\hline & & & & (cps) & $(\%)^{c}$ & \\
\hline & & 4.3 & 20.8 & 504 & 20 & Quartz, $\alpha$-tridymite \\
\hline & & 4.0 & 22.0 & 120 & 5 & Opal-CT \\
\hline & & 3.8 & 23.5 & 144 & 6 & $\alpha$-tridymite \\
\hline & & 3.7 & 24.2 & 109 & 4 & Erionite? \\
\hline & & 3.35 & 26.6 & 2550 & 100 & Illite, quartz \\
\hline & & 3.2 & 27.7 & 190 & 7 & Zeolites \\
\hline & & 3.0 & 29.8 & 117 & 5 & Clinoptilolite? \\
\hline & & 2.8 & 31.6 & 95 & 4 & Cristobalite \\
\hline \multirow[t]{12}{*}{$47 \mathrm{X}-3,25-27$ (SEM) } & 439.45 & 4.5 & 19.7 & 219 & 12 & Chlorite, illite \\
\hline & & 4.3 & 20.8 & 391 & 22 & Quartz, $\alpha$-tridymite \\
\hline & & 4.0 & 22.0 & 118 & 7 & Opal-CT \\
\hline & & 3.9 & 22.8 & 98 & 5 & Clinoptilolite? \\
\hline & & 3.8 & 23.5 & 132 & 7 & $\alpha$-tridymite \\
\hline & & 3.7 & 24.2 & 98 & 5 & Erionite? \\
\hline & & 3.35 & 26.6 & 1787 & 100 & Illite, quartz \\
\hline & & 3.2 & 27.8 & 181 & 10 & Zeolites \\
\hline & & $3.1(4)$ & 28.4 & 125 & 7 & Cristobalite?, zeolites \\
\hline & & $3.1(0)$ & 28.7 & 103 & 6 & Saponite?, zeolites \\
\hline & & $3.0(5)$ & 29.3 & 113 & 6 & Calcite? \\
\hline & & 3.0 & 29.7 & 114 & 6 & Clinoptilolite? \\
\hline \multirow[t]{9}{*}{$47 X-5,102-104$} & 443.22 & 7.1 & 12.4 & 69 & 2 & Chlorite, kaolinite, phillipsite \\
\hline & & 4.5 & 19.7 & 194 & 5 & Chlorite, illite \\
\hline & & 4.3 & 20.8 & 606 & 16 & Quartz, $\alpha$-tridymite \\
\hline & & 4.0 & 22.0 & 109 & 3 & Opal-CT, phillipsite \\
\hline & & 3.8 & 23.5 & 108 & 3 & $\alpha$-tridymite \\
\hline & & 3.36 & 26.5 & 3834 & 100 & Illite, quartz \\
\hline & & 3.2 & 27.9 & 169 & 4 & Zeolites \\
\hline & & 3.1 & 28.4 & 126 & 3 & Cristobalite?, saponite?, zeolites \\
\hline & & 3.0 & 29.8 & 104 & 3 & Clinoptilolite? \\
\hline \multirow{6}{*}{$48 \mathrm{X}-1,100-102$} & 446.90 & 4.5 & 19.8 & 193 & 5 & Chlorite, illite \\
\hline & & 4.3 & 20.8 & 616 & 17 & Quartz, $\alpha$-tridymite \\
\hline & & 4.0 & 22.0 & 90 & 2 & Opal-CT \\
\hline & & 3.8 & 23.5 & 110 & 3 & $\alpha$-tridymite \\
\hline & & 3.36 & 26.5 & 3642 & 100 & Illite, quartz \\
\hline & & 3.2 & 27.6 & 163 & 4 & Zeolites \\
\hline \multirow{8}{*}{$48 X-3,99-101$} & 449.90 & 4.5 & 19.8 & 211 & 7 & Chlorite, illite \\
\hline & & 4.3 & 20.8 & 618 & 20 & Quartz, $\alpha$-tridymite \\
\hline & & 4.1 & 22.0 & 113 & 4 & Opal-CT \\
\hline & & 3.8 & 23.5 & 132 & 4 & $\alpha$-tridymite \\
\hline & & 3.35 & 26.6 & 3084 & 100 & Illite, quartz \\
\hline & & 3.2 & 27.7 & 212 & 7 & Zeolites \\
\hline & & 3.1 & 28.4 & 115 & 4 & Cristobalite?, saponite?, zeolites \\
\hline & & 3.0 & 29.8 & 112 & 4 & Clinoptilolite? \\
\hline
\end{tabular}

Notes: The XRD analyses were carried out on bulk samples, without any treatment or separation, in the Department of Chemistry of the University of Waterloo. $\mathrm{A} \mathrm{Cu}_{\mathrm{Ka}}$ source was used in a Siemens D500 diffractometer at a scan rate of $0.015^{\circ} / \mathrm{s}$, from $8^{\circ}$ to $32^{\circ}(2 \theta)$.

a "SEM" after the sample number indicates that a portion of the sample was also used for scanning electron microscopy work.

${ }^{b}$ The peaks are arranged in order of their $2 \theta$ values.

${ }^{c}$ Relative peak height is expressed as a percentage of the sample maximum peak intensity.

d "Opal-CT" indicates undifferentiated cristobalite and tridymite. "Zeolites" are undifferentiated zeolite phases, though the most common are clinoptilolite and phillipsite, and analcime and laumontite are not uncommon. The height and width of the peaks frequently prevent the resolution of specific phases. For sections $127-797 \mathrm{~B}-31 \mathrm{X}-1$ through $-33 \mathrm{X}-3$, the quartz is detrital in origin, and is flagged with an asterisk $\left(^{*}\right)$. References: Finney et al. (1975), Chen et al. (1978), Hawkins et al. (1978), JCPDS (1978), Gottardi and Galli (1985), and Roberts et al. (1990).

physical properties occur below 325 mbsf, the previously defined boundary (Shipboard Scientific Party, 1990f), between 326 mbsf (based on the GRAPE density) and 328 mbsf (based on the more coarsely sampled index properties). There is little significant change in the Site 796 downhole logging profiles at $225 \mathrm{mbsf}$, the previously defined boundary (Shipboard Scientific Party, 1990g), but the profiles do exhibit a marked change between 212 and 213 mbsf. The Site 798 data change most rapidly at $451 \mathrm{mbsf}$, some $4 \mathrm{~m}$ above the previously defined opal-A/opal-CT boundary (Shipboard Scientific Party, 1990i); however, the data below the boundary are highly variable and the position is thus uncertain. Similarly, the sharpest changes in the Site 799 profiles occur just above 440 mbsf, rather than at the previously defined boundary of 457 mbsf (Shipboard Scientific Party, 1990j). However, there are significant excursions at approximately $459 \mathrm{mbsf}$ and at $467 \mathrm{mbsf}$, as well, so that the placement of the Site 799 opal-A/opal-CT boundary is not exact. The sampling is coarse just below 467 mbsf, and the profile is not complete. The boundaries as defined previously and as assigned on the basis of the physical property and downhole logging profiles are summarized in Table 3.

The shifts in the opal-A/opal-CT boundaries give rise to minor adjustments in the temperatures at the boundaries as calculated from measured temperature gradients (Tamaki, Pisciotto, Allan, et al., 1990; Ingle, Suyehiro, von Breymann, et al., 1990). The temperatures at the diagenetic boundaries are $37.5^{\circ} \mathrm{C}$ at $293.5 \mathrm{mbsf}$ for Site 794 , $43^{\circ}-44^{\circ} \mathrm{C}$ at $326-329 \mathrm{mbsf}$ for Site $795,38.0^{\circ} \mathrm{C}$ at $212.5 \mathrm{mbsf}$ for Site $796,36.9^{\circ} \mathrm{C}$ at $303 \mathrm{mbsf}$ for Site 797 , and $43^{\circ}-45^{\circ} \mathrm{C}$ at 439-459 mbsf for Site 799. The gradient at Site 798 is poorly defined (Shipboard Scientific Party, 1990i), and we obtain temperatures from a low of $41^{\circ} \mathrm{C}$ to a high of $50^{\circ} \mathrm{C}$ at $451 \mathrm{mbsf}$. The temperature at the opal-A/opal-CT boundary is therefore $40^{\circ} \pm$ $3^{\circ} \mathrm{C}$, excluding Site 798 . 

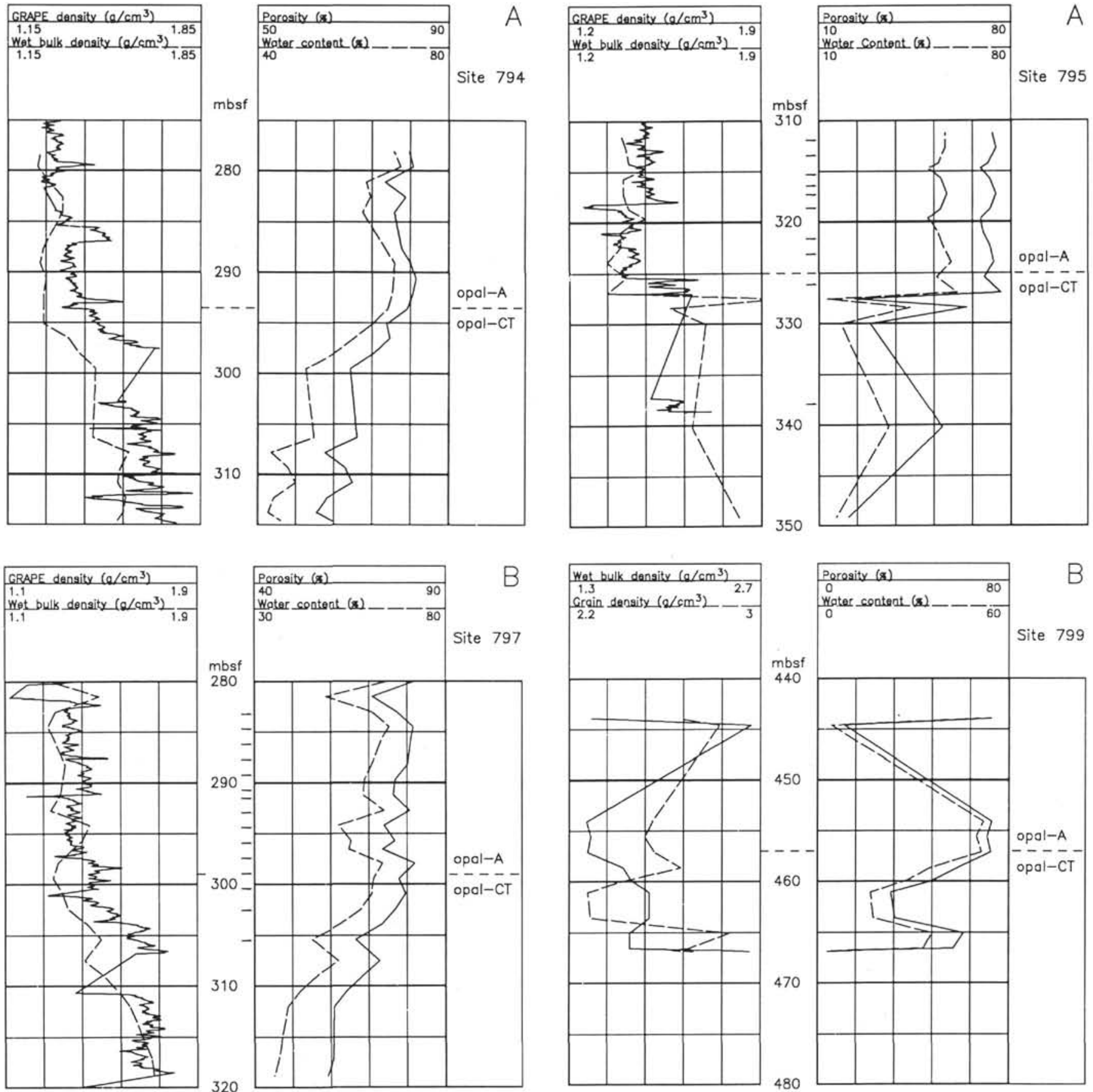

Figure 5. Sites 794 (A) and 797 (B) wet-bulk and smoothed GRAPE densities (left) and porosity and water content (right), in API format, across the opal-A/ opal-CT boundary, as defined by shipboard XRD analyses. Note the apparently smooth change in the physical properties across the boundary. The tick marks at the right of the Site 797 depth column (center, B) mark the locations of the residues used for XRD and SEM analyses.

As discussed earlier, the physical properties and downhole logging data, particularly the Al yield, the resistivity, the acoustic velocity, and the computed $\mathrm{Th}+\mathrm{K}$ gamma-ray emission, change, often markedly, across the diagenetic transition zone, as we see for Site 797 (Figs. 4, $5 \mathrm{~B}$, and 10 ). While Site 795 seems to show a sharp change in the physical properties across the opal-A/opal-CT boundary (Fig. 6A), the sampling is coarse and logging did not reach the depth of the transition zone, so that we may not examine the effect of the transition

Figure 6. Sites 795 (A) and 799 (B) wet-bulk density (left) and porosity and water content (right) across the opal-A/opal-CT boundaries, as defined by shipboard XRD analyses. The Site 795 smoothed GRAPE density and Site 799 grain density are also shown. The changes across the boundaries appear to be sharper and concurrently more variable than at Sites 794 or 797 (Fig. 5); the sampling, however, is coarser. The XRD and SEM sample locations are indicated by the tick marks on the right hand side of the Site 795 depth column (center, A).

more closely. We do, however, have logging data and the detailed GRAPE density record for Site 794 with which to construct a more complete and detailed picture of the opal-A to opal-CT transition.

When we overlay the profiles for Sites 794 and 797 (Figs. 11 and 12 ), the similarities are profound; even some small variations are repeated in the individual profiles for the two widely separated sites. 

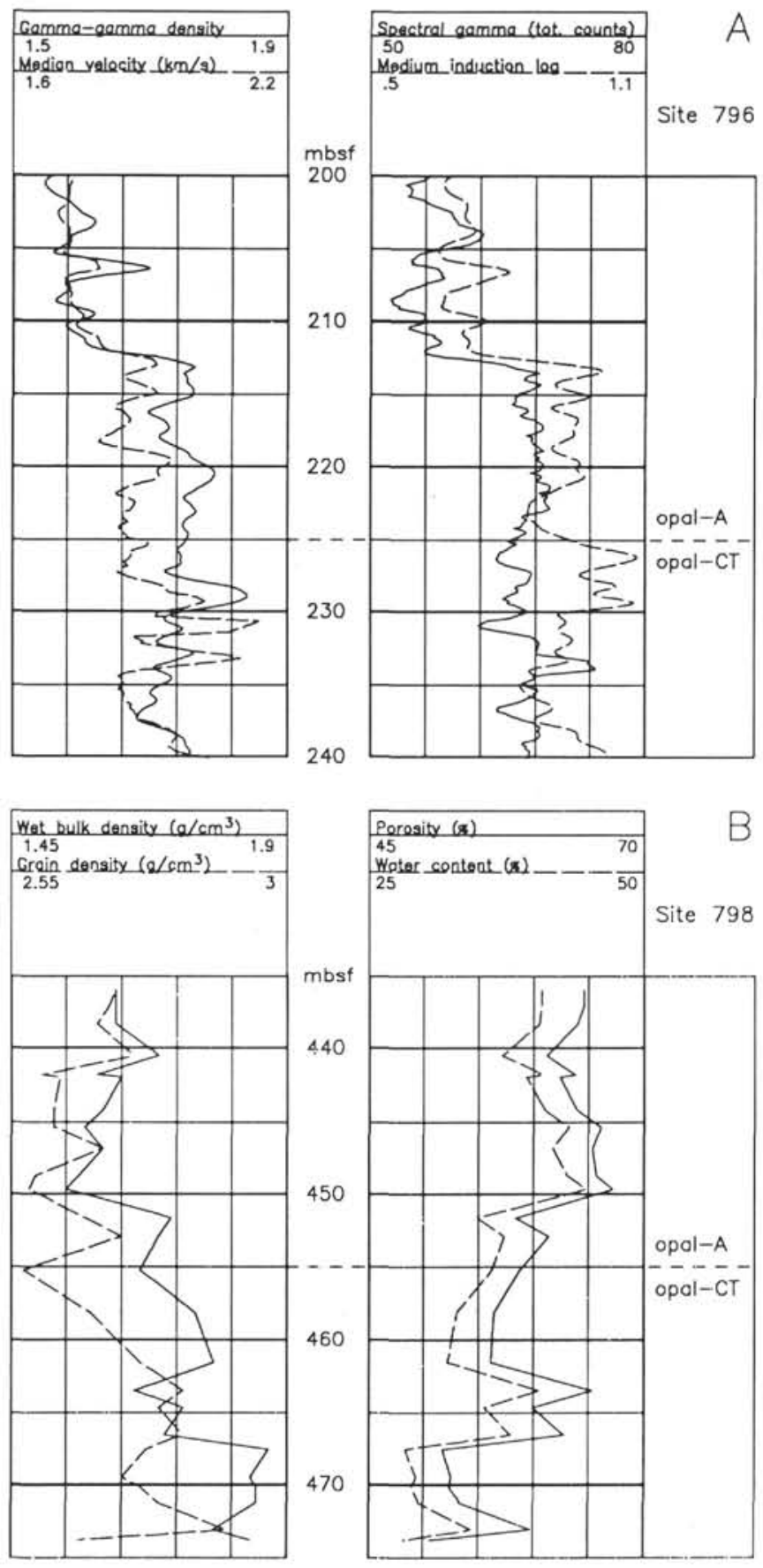

Figure 7. A. Selected Site 796 downhole logging data across the opal-A/ opal-CT boundary. The index property data were poorly sampled across this interval. The density and sonic velocity (left) largely reflect changes in porosity; the total spectral gamma and medium induction log resistivity (right) depend on porosity and clay content. Note the sharp changes in the profiles at approximately 212 to 213 mbsf, above the previously defined opal-A/opal-CT boundary. B. Site 798 wet-bulk and grain densities (left) and porosity and water content (right) across the opal-A/opal-CT boundary; GRAPE density was not available. The changes across the boundary as defined by shipboard XRD analyses are not prominent, but a sharp change in the profiles occurs at a shallower depth ( $450 \mathrm{mbsf})$ which may be a more suitable opal-A/ opal-CT boundary.
Table 3. Diagenetic boundaries, Legs 127 and 128.

\begin{tabular}{|c|c|c|c|c|}
\hline \multirow[b]{2}{*}{ Site } & \multicolumn{2}{|c|}{$\begin{array}{l}\text { Opal-A/opal-CT } \\
\text { boundary (mbsf) }\end{array}$} & \multicolumn{2}{|c|}{$\begin{array}{l}\text { Opal-CT/quartz } \\
\text { boundary (mbsf) }\end{array}$} \\
\hline & Previous $^{\mathrm{a}}$ & This study & Previous ${ }^{a}$ & This study \\
\hline 794 & 293.5 & 293.5 & 395 & 394 \\
\hline 795 & 325 & 326 or 329 & 471 & 465 \\
\hline 796 & 225 & 213 & \multicolumn{2}{|c|}{ Not drilled } \\
\hline 797 & 299 & 303 & 427.5 & 427.5 \\
\hline 798 & 455 & $451 ?$ & \multicolumn{2}{|c|}{ Not drilled } \\
\hline 799 & 457 & 439 or $459 ?$ & \multicolumn{2}{|c|}{${ }^{\mathrm{b}}$ Unchanged } \\
\hline
\end{tabular}

"References: See individual site chapters in Tamaki, Pisciotto, Allan, et al., 1990.

b "Unchanged" means that there was not enough evidence to confirm or to alter the boundary.

The porosity indicator ratios, while of different amplitudes, have similar shapes (Fig. 11). The density (Fig. 11) and gamma-ray emission (Fig. 12) profiles follow similar gentle slopes, reaching local maxima just below the opal-A/opal-CT boundary. The velocity (Fig. 11) and aluminum (Fig. 12) profiles increase sharply across the boundary. The resistivity (Fig. 12) profiles are intermediate in slope. The velocity and the resistivity both reach maximum values just below the boundary, before decreasing and then increasing again. Finally, the gamma-ray emission profiles have similar slopes, and the alternating maximum and minimum values just below the diagenetic boundary follow a similar pattern (Fig. 12).

Taken in combination, the profile patterns are primarily recording the effects of changing porosity. For example, the natural gamma logs, the computed $\mathrm{Th}+\mathrm{K}$, for example, and the resistivity logs-the medium induction log, for instance-will vary in opposite directions in response to changes solely in clay content. However, both sets of natural gamma and resistivity logs will increase if the porosity decreases, just as we observe. We see layers of slightly elevated and diminished porosity across the opal-A/opal-CT boundary, which appears as a major porosity decrease.

The thickness of the transition zone is not clearly defined, but will vary depending on the temperature, depth of burial (i.e., pressure), and lithologic parameters. The slopes of both sets of profiles become large at the boundary, and we might define the transition zone as that portion of the section where the slopes in the profiles are the steepest, just as we did for the position of the boundary. In that case, the zone is about $1 \mathrm{~m}$ wide using the density, gamma ray, and resistivity profiles. If we define the zone as that section of the profile where a noticeable change takes place, then the slow but steady increase in gamma-ray yield and in density begins as much as $6 \mathrm{~m}$ above the opal-A to opal-CT boundary, as defined by the sharpest changes in the profiles, and both sets of profiles reach maximum values just below, and generally within $2 \mathrm{~m}$ of, the boundary. The Al yields, GRAPE densities, and the acoustic velocities start to increase, albeit sometimes slowly, in a steady fashion as much as $6 \mathrm{~m}$ above the boundary. The Site 794 natural gamma and resistivity logs are parallel, indicating that the porosity is the major parameter that is varying, more than $10 \mathrm{~m}$ above the opal-A/opal-CT boundary, and the parallel response ceases within $2 \mathrm{~m}$ below the boundary. Based on the parallel and consistent variations in the physical properties, the opal-A to opal-CT transition zone is as much as $12 \mathrm{~m}$ wide. We recognize, however, that other interpretations may yield different results-for example, based on diatom preservation or on interstitial water gradients. The width of the transition zone indicates that while the temperature at the opal-A/opal-CT boundary may characterize the diagenetic transition, a $2^{\circ} \mathrm{C}$ temperature range may be more appropriate. 


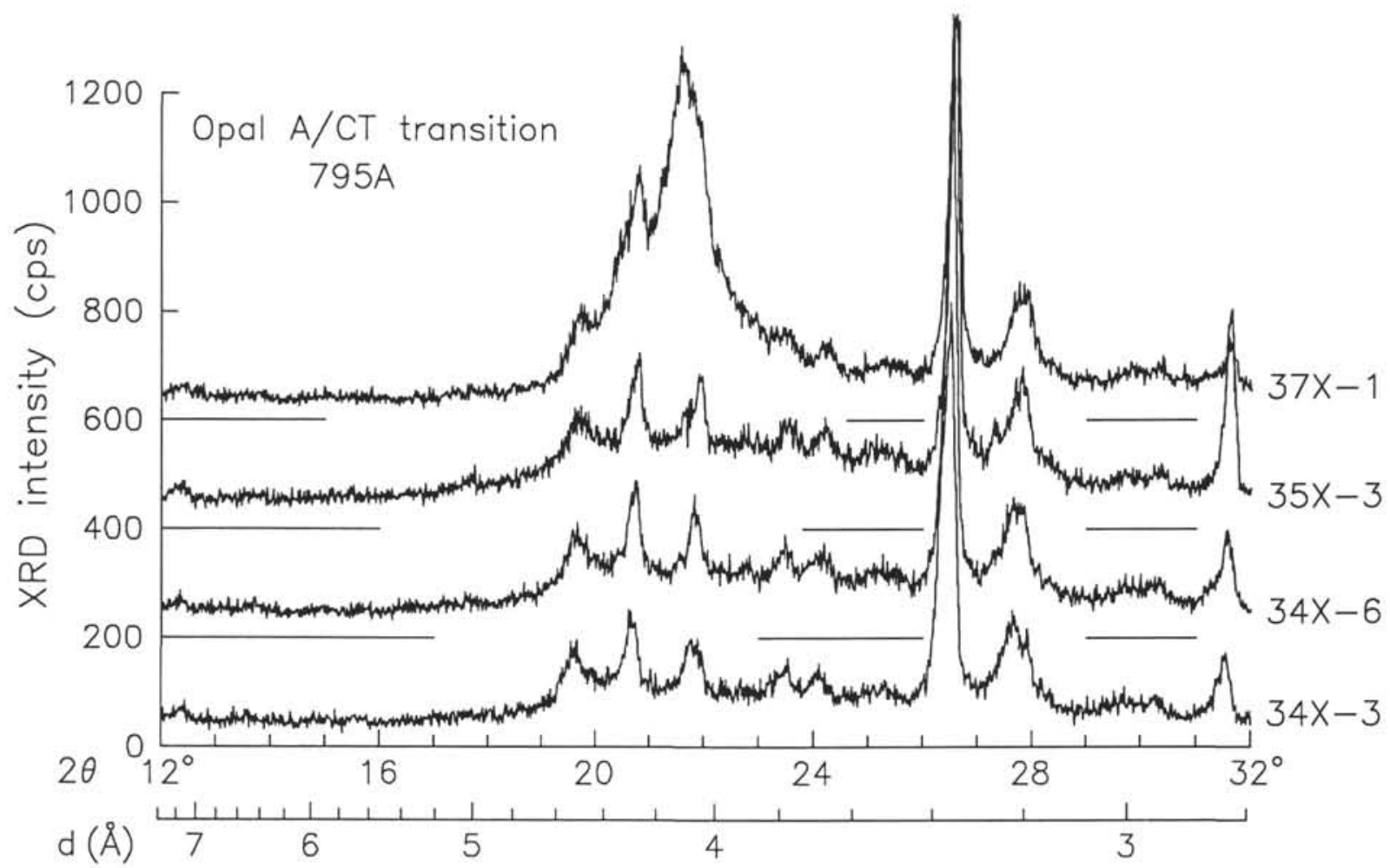

Figure 8. XRD intensity vs. $2 \theta$ and d-spacing across the opal-A to opal-CT transition for Site 795 . A detrital quartz peak is present at $26.5^{\circ}$ $(3.36 \AA)$. The peaks at $21.8^{\circ}, 23.5^{\circ}$, and $31.6^{\circ}(4.1 \AA, 3.8 \AA$, and $2.8 \AA$, respectively) suggest the presence of incipient opal-CT. The CT peak rises sharply in Section 127-795A-37X-1. The XRD peaks are listed in Table 1.

Site 794 has the most clearly defined chemical signal of biogenic input through the diatomaceous sequence, while Site 795 has the lowest, and Site 797 is intermediate (Murray et al., this volume). These differences cannot be directly investigated because of the lack of logging data from Site 795. It is interesting to note, however, that diatoms (opal-A) and opal-CT were plentiful and common in the SEM samples from Site 795, with little zeolite, whereas for Site 797, there were fewer complete diatoms, and much more zeolite. We may simply be observing some variability due to the particular sample selection, but the differences appear to be consistent. The lithologic differences between Sites 794 and 797 had apparently little effect on the physical property and logging profiles across the opal-A to opal-CT transition, since many of the details in the physical property profiles were the same. The at-times striking similarities suggest that the details may be connected with the diagenetic process itself.

\section{Opal-CT to Quartz Transition}

The opal-CT to quartz transformation is harder to characterize because of the poorer core recovery across these intervals. Nonetheless, the transition appears sharp and distinct as illustrated by the index properties from Site 795 (Fig. 13A), the downhole logging data from Site 797 (Fig. 13B), and the XRD results for those samples from Sites 795 and 797 that bracket the opal-CT to quartz transition (Fig. 14). As before, the XRD results are listed in Tables 1 and 2 for Sites 795 and 797, respectively. In addition, the SEM photographs for Samples 127. 795B-11R-2, 81-83 cm, and -11R-3, 120-122 cm, are shown in Plate 4. All of the results indicate a sharp transition from opal-CT to quartz.

The results from Site 795 constrain the thickness of the transition layer to $1.8 \mathrm{~m}$ or less (between 464.01 and $465.9 \mathrm{mbsf}$ ), but the coarse sampling and the lack of logging data do not allow us to reduce this limit. At Site 797, on the other hand, the logging data (Fig. 13) indicate that the transition zone is less than $1 \mathrm{~m}$ thick. In addition, Pisciotto et al. (this volume) found clear diagenetic quartz in Sample 127-797B$46 \mathrm{X}-1,146-150 \mathrm{~cm}$, at $428.06 \mathrm{mbsf}$, which again indicates that the opal-CT to quartz transition occurs within a zone that is at most $1 \mathrm{~m}$ thick. The results from Site 794 (not shown) are less clear, but suggest that the transition zone lies at about 394 mbsf, $1 \mathrm{~m}$ above the previously defined boundary (Shipboard Scientific Party, 1990e), and again is approximately $1 \mathrm{~m}$ thick. The results from Site 799 (also not shown) display little variability across the opal-CT/quartz boundary and cannot be used to study the transition because its position cannot be accurately estimated nor can we examine the manner in which physical properties change across the boundary. The opal-CT/quartz boundaries as previously defined and as adjusted here are listed in Table 3. The temperatures at the boundaries can be estimated from the temperature gradients, as we did for the opal-A/opal-CT boundary. The results are essentially the same as the values reported previously (Tamaki, Pisciotto, Allan, et al., 1990), and range from approximately $46^{\circ} \mathrm{C}$ at Site 794 , to $56^{\circ} \mathrm{C}$ at Site 795 , with a value of about $47.5^{\circ} \mathrm{C}$ at Site 797 .

\section{Physical Property Interrelationships}

Another way to compare the physical properties for the sediments above and below the diagenetic boundaries is through the use of crossplots, which are widely used in downhole logging interpretation (see, for example, Ellis, 1987). We may examine how well the physical property data follow theoretical model curves, and how the data cluster, if indeed the data form clusters at all.

For Sites 794 and 797, for example, we compared the downhole logging and GRAPE density profiles across the opal-A/opal-CT boundaries. When we plot the wet-bulk density (WBD), grain density, acoustic velocity, and thermal conductivity as functions of the porosity (Fig. 15), we see first of all that WBD, velocity, and thermal conductivity 


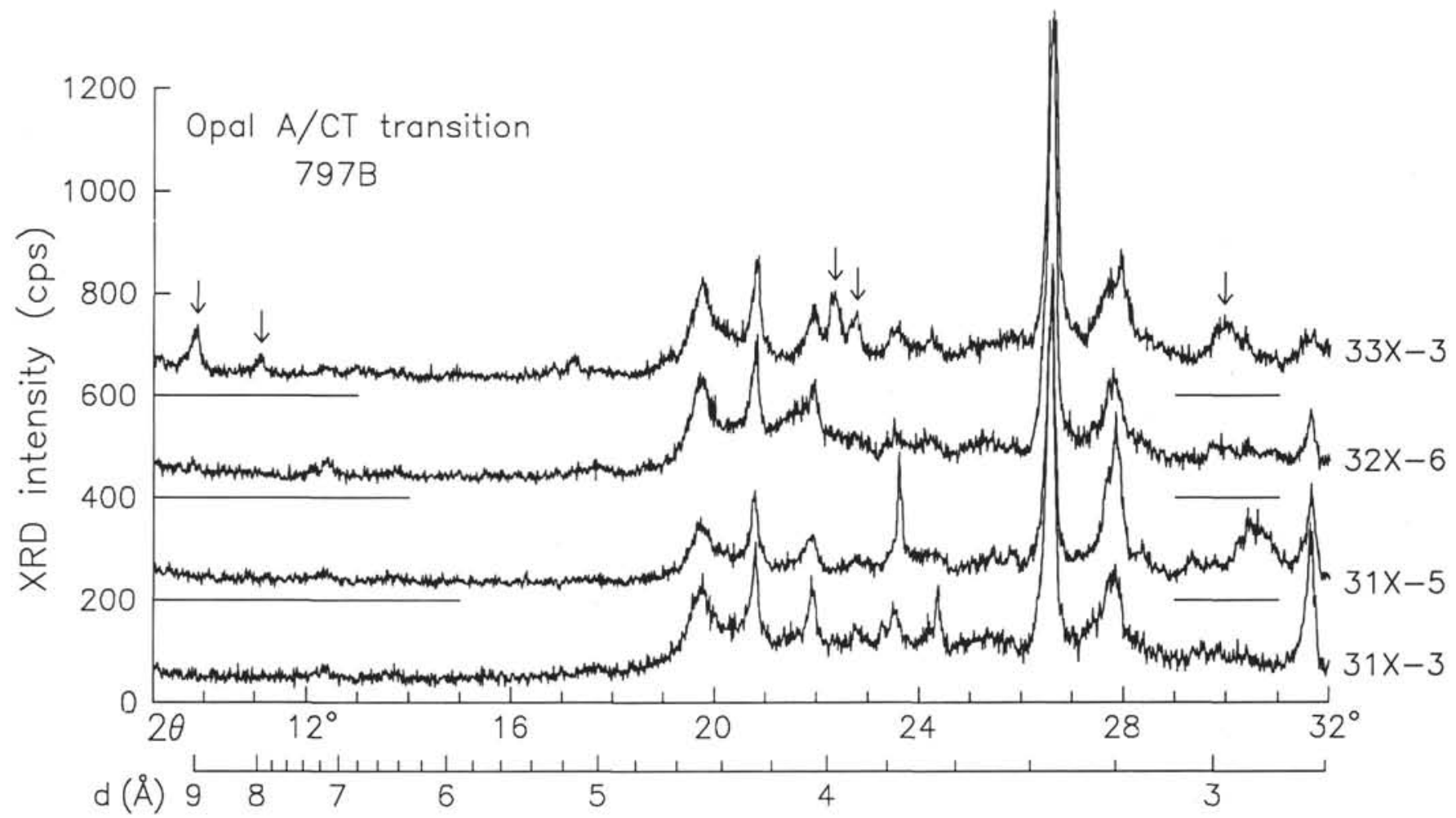

Figure 9. XRD intensity vs $2 \theta$ and d-spacing across the opal-A to opal-CT transition for Site 797 . A detrital quartz peak is present at $26.5^{\circ}(3.36 \AA)$, and peaks at $21.8^{\circ}, 23.5^{\circ}$, and $31.6^{\circ}(4.1 \AA, 3.8 \AA$, and $2.8 \AA$, respectively) indicate that opal-CT is present. A significant rise in the CT peak, however, is not observed. A set of five clinoptilolite peaks (marked by the arrows) is present for Section 127-797B-33X-3; clinoptilolite, a zeolite, is observed in the SEM samples (see PI. 3). The XRD peaks are listed in Table 2.

in general follow theoretical model curves. The WBD data tend to cut across the trends defined by the model curves (Fig. 15A), suggesting an increase in the grain density with decreasing porosity. While such a trend may be present, the most notable feature of the grain density is its low value and high variability at high porosities, reflecting the variation in the opal-A and clay contents. The grain density of opal-A can be as low as $1.89 \mathrm{~g} / \mathrm{cm}^{3}$; the grain density of clay varies from a low of $2.3 \mathrm{~g} / \mathrm{cm}^{3}$ for palygorskite, to a high of $2.8 \mathrm{~g} / \mathrm{cm}^{3}$ for chlorite (Johnson and Olhoeft, 1984). Zeolites, such as clinoptilolite, have intermediate values of $2.1 \mathrm{~g} / \mathrm{cm}^{3}$. The thermal conductivity data are scattered but clearly follow the trend of a geometric mean model (Fig. 15D).

The acoustic velocity tends to follow the trends indicated by the theoretical models in the sediments below the opal-A/opal-CT boundary (Fig. 15C), but above the opal-A/opal-CT boundary, the velocity does not vary with porosity in a systematic way. Instead, the velocity appears to take on a particular value, and then at the opal-A/opal-CT boundary begins to increase as the porosity decreases. There appears to be a threshold above which the velocity is almost unvarying, and below which the velocity increases. This feature is most apparent when we plot the sonic velocity vs. the porosity calculated from the density $\log$ (Fig. 16). The presence of a threshold or critical porosity has also been observed by Chen and Nur (1991) and Nur et al. (1991). The data form clusters: one for sediments above the opal-A/opal-CT boundary and another for sediments below that boundary. There is a marked separation of the two clusters, one of which, for sediments above the opal-A/opal-CT boundary, shows little variation with porosity, while the other follows a clear trend with velocity increasing as the porosity decreases.

The data for Sites 795 and 799 (Fig. 17) have many of the same features as we see in the Site 794 and 797 data, but display variations arising from lithologic differences. For example, the acoustic velocity vs. porosity for Site 795 follows a model curve that is appropriate for high-clay content (Fig. 17C). This is consistent with the observation that Site 795 has the least clearly defined chemical signal of biogenic input (Murray et al., this volume). In contrast, the Site 799 velocity and thermal conductivity data cut across model curves or follow trends that represent sediments with higher carbonate content, and lower silica and clay contents, particularly for sediments below the opal-CT/quartz boundary. This feature is consistent with the observed lithology at Site 799, where carbonate beds, laminae, and concretions are present between the opal-A/opal-CT and opal-CT/quartz boundaries, and carbonate-rich laminae, lenses, and nodules are observed below the opal-A/quartz boundary.

\section{CONCLUSIONS}

The physical property and downhole logging data do show the effects of silica diagenesis and can be used to locate the diagenetic boundaries and to examine the details of the processes. Based on the variations in index properties, GRAPE density, and downhole logging data, correlated with the XRD and SEM observations, we have adjusted the placement of the opal-A to opal-CT boundaries at the Leg 127 and 128 sites. The opal-A to opal-CT transition zones are $10 \mathrm{~m}$ or more thick, since opal-A dissolution and incipient opal-CT occur well above the opal-A to opal-CT boundary. The variations of the index property and logging data across the opal-A to opal-CT boundaries at Sites 794 and 797 are similar; even some of the small-scale detail is the same, reflecting porosity variations that appear to be associated with the change from opal-A to opal-CT. The high degree of similarity is thus due to the process of diagenesis. The physical property variations, particularly when plotted against porosity, show that the properties on either side of the opal-A/opal-CT boundary are distinct. This is best illustrated by the acoustic velocity, which has an almost constant value above the boundary, but follows theoretical trends below the boundary. 

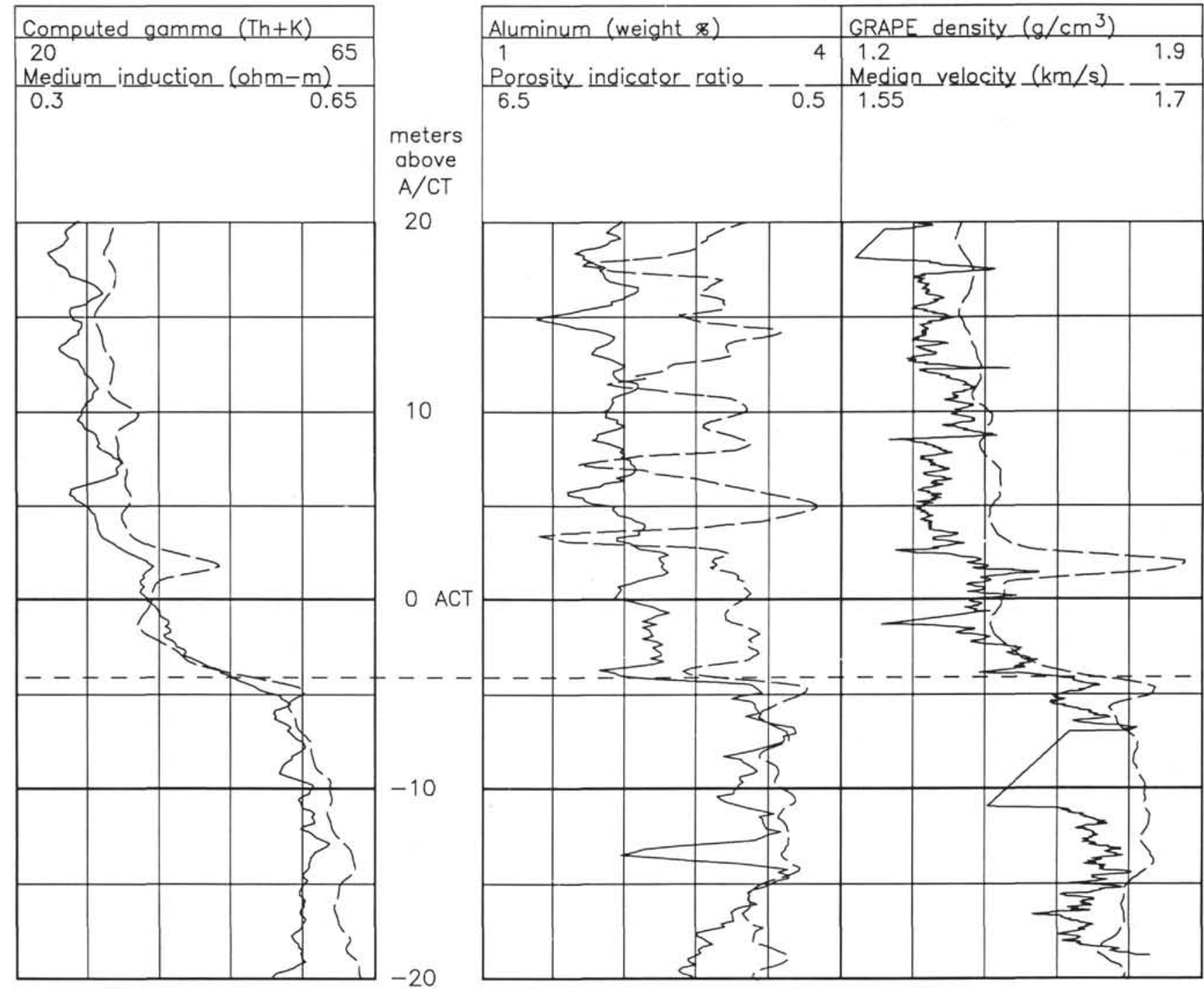

Figure 10. A detailed view of the GRAPE density and downhole logging variations across the opal-A/opal-CT boundary at Site 797. The profiles have been smoothed to better show the changes in the profiles, unobscured by the large variability that is often present. The profiles have been depth-corrected, and the depth scale has been shifted to place zero at the opal-A/opal-CT boundary, as defined by shipboard analyses, to show how the placement of the boundary may be shifted from its previously defined position. The largest changes in the profiles occur approximately $4 \mathrm{~m}$ below the original position (as indicated by the dashed line), which suggests that the opal-A/opal-CT boundary should be placed $4 \mathrm{~m}$ deeper.

In contrast, the physical properties on either side of the opal-CT/ quartz boundary overlap when plotted against the porosity, and cannot be clearly separated. Nonetheless, the opal-CT to quartz transition is clear and sharp in all data sets, and occurs in a zone that is at most $1 \mathrm{~m}$ wide. The depths for the opal-CT/quartz boundaries have been adjusted from previously assigned values for Sites 794, 795, and 797.

The temperatures at the diagenetic boundaries are similar to values computed previously, since the depths of the boundaries have been shifted by only small amounts. The temperature at the opal-A/opal-CT boundary is $40^{\circ} \pm 3^{\circ} \mathrm{C}$, and the temperatures at the opal-CT/quartz boundary range from $46^{\circ}$ to $56^{\circ} \mathrm{C}$.

\section{ACKNOWLEDGMENTS}

DCN recognizes the support of the Natural Sciences and Engineering Research Council of Canada through a Collaborative Special Projects Grant. This work was performed while RMW held a JOI/USSAC Cruise Science Support grant and a shore-based JOI/USSAC Ocean Drilling
Fellowship. We acknowledge the assistance of the ODP marine technicians, in particular Mark Simpson. We thank the Leg 127 co-chief scientists, the staff scientist, and Peggy Myre, the curatorial representative, for their flexibility and assistance with modified sample requests. Dale Weber provided instruction and assistance with the SEM. Steve Herz carried out the XRD work. Linda Nazar of the Department of Chemistry at the University of Waterloo allowed us access to her X-ray diffractometer.

\section{REFERENCES}

Borehole Research Group, 1988. Wireline Logging Manual: Palisades, NY (Lamont-Doherty Borehole Research Group).

Chen, Q., and Nur, A., 1991. Critical concentration models for the mechanical and acoustic properties of porous rocks and sediments. Eos, 72:438.

Chen, N. Y., Reagan, W. J., Kokotailo, G. T., and Childs, L. P., 1978. A survey of catalytic properties of North American clinoptilolites. In Sand, L. B., and Mumpton, F. A. (Eds.), Natural Zeolites: Oxford (Pergamon Press), $411-420$. 
Ellis, D. V., 1987. Well Logging for Earth Scientists: New York (Elsevier).

Finney, J. J., Briceno, H., and Gobel, V., 1975. X-ray Data for Minerals: Golden, CO (Colorado School of Mines).

Gottardi, G., and Galli, E., 1985. Natural Zeolites: Berlin (Springer-Verlag).

Hawkins, D. B., Sheppard, R. A., and Gude, A. J., 1978. Hydrothermal synthesis of clinoptilolite and comments on the assemblage phillipsiteclinoptilolite-mordenite. In Sand, L. B., and Mumpton, F. A. (Eds.), Natural Zeolites: Oxford (Pergamon Press), 337-343.

Hesse, R., 1988. Origin of chert: diagenesis of biogenic siliceous sediments. Geosci. Can., 15:171-192.

Iijima, A., and Tada, R., 1981. Silica diagenesis of Neogene diatomaceous and volcaniclastic sediments in northern Japan. Sedimentology, 28:185-200.

Ingle, J. C., Jr., Suyehiro, K., von Breymann, M. T., et al., 1990. Proc. ODP, Init. Repts., 128: College Station, TX (Ocean Drilling Program).

Isaacs, C. M., Pisciotto, K. A., and Garrison, R. E., 1983. Facies and diagenesis of the Monterey Formation, California: a summary. In lijima, A., Hein, J. R., and Siever, R. (Eds.), Siliceous Deposits in the Pacific Region: Amsterdam (Elsevier), 247-282.

JCPDS, 1978. Selected Powder Diffraction Data for Metals and Alloys: Swarthmore, PA (JCPDS International Center for Diffraction Data).

Johnson, G. R., and Olhoeft, G. R., 1984. Density of rocks and minerals. In Carmichael, R. S. (Ed.), Handbook of Physical Properties of Rocks and Minerals (Vol. 3): Boca Raton, FL (CRC Press), 1-38.

Kastner, M., 1979. Zeolites. In Burns, R. G. (Ed.), Marine Minerals. Rev. Mineral., 6:111-122.

- 1981. Authigenic silicates in deep-sea sediments: formation and diagenesis. In Emiliani, C. (Ed.), The Sea (Vol. 7): The Oceanic Lithosphere: New York (Wiley), 915-980.

Kastner, M., and Gieskes, J. M., 1983. Opal-A to opal-CT transformation: a kinetic study. In lijima, A., Hein, J. R., and Siever, R. (Eds.), Siliceous Deposits in the Pacific Region: Amsterdam (Elsevier), 211-227.

Kastner, M., Keene, J. B., and Gieskes, J. M., 1977. Diagenesis of siliceous oozes. I: Chemical controls on the rate of opal-A to opal-CT transformation-an experimental study. Geochim. Cosmochim. Acta, 41:1041-1059.

Mumpton, F. A., and Ormsby, W.C., 1978. Morphology of zeolites in sedimentary rocks by scanning electron microscopy. In Sand, L. B., and Mumpton, F. A. (Eds.), Natural Zeolites: Oxford (Pergamon Press), 113-132.

Nobes, D. C., 1989. A test of a simple model of the acoustic velocity in marine sediments. J. Acoust. Soc. Am., 86:290-294.

Nobes, D. C., Mienert, J., and Dirksen, G. J., 1991. Lithologic control of physical property interrelationships. In Ciesielski,P.F., Kristoffersen, Y., et al., Proc. ODP, Sci. Results, 114: College Station, TX (Ocean Drilling Program), 657-669.

Nur, A., Marion, D., and Yin, H., 1991. Wave velocities in sediments. In Hovem, J. M., et al. (Eds.), Shear Waves in Marine Sediments: Dordrecht (Kluwer Acad.), 131-140.

Pisciotto, K. A., 1981a. Diagenetic trends in the siliceous facies of the Monterey Shale in the Santa Maria region, California. Sedimentology, 28:547-571.

, 1981b. Distribution, thermal histories, isotopic compositions, and reflection characteristics of siliceous rocks recovered by the Deep Sea Drilling Project. In Warme, J. E., Douglas, R. G., and Winterer, E. L. (Eds.), The Deep Sea Drilling Project: A Decade of Progress, Spec. Publ.-Soc. Econ. Paleontol. Mineral., 32:129-148.

Roberts, W. J., Campbell, T. J., and Rapp, G. R., Jr., 1990. Encyclopedia of Minerals (2nd ed.): New York (Van Nostrand Reinhold).
Shipboard Scientific Party, 1990a. Background, objectives, and principal results, ODP Leg 127, Japan Sea. In Tamaki, K., Pisciotto, K., Allan, J., et al., Proc. ODP, Init. Repts., 127: College Station, TX (Ocean Drilling Program), 5-33.

, 1990b. Explanatory notes. In Ingle, J. C., Jr., Suyehiro, K., von Breymann, M. T., et al., Proc. ODP, Init. Repts., 128: College Station, TX (Ocean Drilling Program), 39-64.

1990c. Explanatory notes. In Tamaki, K., Pisciotto, K., Allan, J., et al., Proc. ODP, Init. Repts., 127: College Station, TX (Ocean Drilling Program), 35-59.

1990d. Introduction, background, and principal results on Leg 128 of the Ocean Drilling Program, Japan Sea. In Ingle, J. C., Jr., Suyehiro, K. von Breymann, M. T., et al., Proc. ODP, Init. Repts., 128: College Station, TX (Ocean Drilling Program), 5-38.

, 1990e. Site 794. In Tamaki, K., Pisciotto, K., Allan, J., et al., Proc. ODP, Init. Repts., 127: College Station, TX (Ocean Drilling Program), $71-167$.

, 1990f. Site 795. In Tamaki, K., Pisciotto, K., Allan, J., et al., Proc. ODP, Init. Repts., 127: College Station, TX (Ocean Drilling Program), 169-245.

, 1990g. Site 796. In Tamaki, K., Pisciotto, K., Allan, J., et al., Proc. ODP, Init. Repts., 127: College Station, TX (Ocean Drilling Program), 247-322.

, 1990h. Site 797. In Tamaki, K., Pisciotto, K., Allan, J., et al., Proc. ODP, Init. Repts., 127: College Station, TX (Ocean Drilling Program), 323-421.

, 1990i. Site 798. In Ingle, J. C., Jr., Suyehiro, K., von Breymann, M. T., et al., Proc. ODP, Init. Repts., 128: College Station, TX (Ocean Drilling Program), 121-236.

1990j. Site 799. In Ingle, J. C., Jr., Suyehiro, K., von Breymann, M. T., et al., Proc. ODP, Init. Repts., 128: College Station, TX (Ocean Drilling Program), 237-402.

Stonecipher, S. A., 1978. Chemistry and deep-sea phillipsite, clinoptilolite, and host sediments. In Sand, L. B., and Mumpton, F. A. (Eds.), Natural Zeolites: Oxford (Pergamon Press), 221-234.

Tada, R., 1991. Compaction and cementation in siliceous rocks and their possible effect on bedding enhancement. In Einsele, G., Ricken, W., and Seilacher, A. (Eds.), Cycles and Events in Stratigraphy: Berlin (SpringerVerlag), $480-491$.

Tada, R., and Iijima, A., 1983. Identification of mixtures of opaline silica phases and its implications for silica diagenesis. In Iijima, A., Hein, J. R., and Siever, R. (Eds.), Siliceous Deposits in the Pacific Region: Amsterdam (Elsevier), 229-245.

Tamaki, K., Pisciotto, K., Allan, J., et al., 1990. Proc. ODP, Init. Repts., 127 College Station, TX (Ocean Drilling Program).

von Rad, U., Reich, H., and Rösch, H., 1978. Silica diagenesis in continental margin sediments off northwest Africa. In Lancelot, Y., Siebold, E., et al., Init. Repts. DSDP, 41: Washington (U.S. Govt. Printing Office), 879-905.

Welton, J. E., 1984. SEM Petrology Atlas. AAPG.

Date of initial receipt: 16 April 1991

Date of acceptance: 11 September 1991

Ms 127/128B-111 


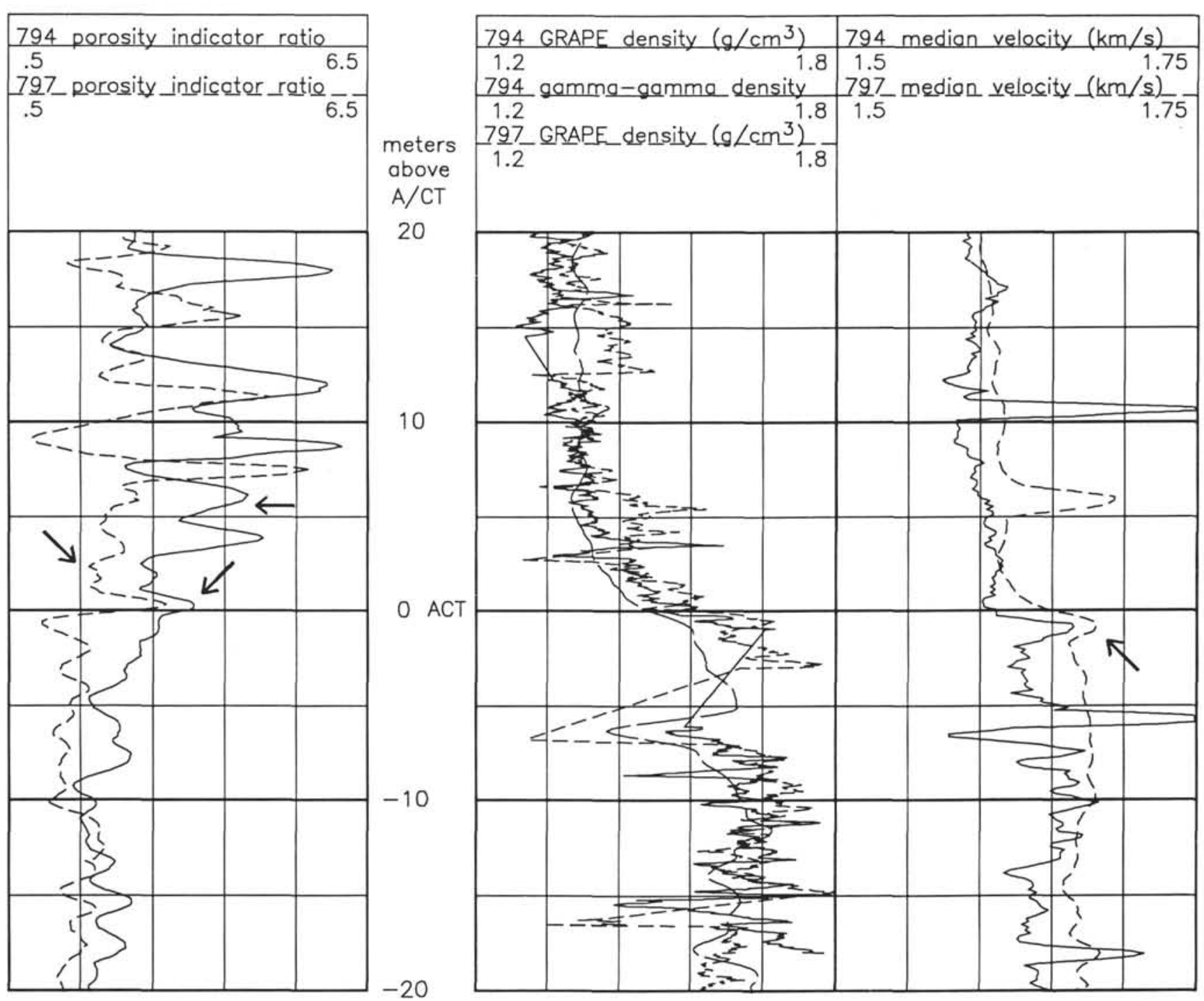

Figure 11. Comparison of the smoothed porosity indicator ratios, the GRAPE and logging densities, and the median velocities for Sites 794 and 797 . The depths have been adjusted to a common scale for easy comparison; the opal-A to opal-CT boundary is taken to be $0 \mathrm{~m}$. Note the excellent correlation between the properties of Sites 794 and 797. Even the detailed variations across the diagenetic transition zone are similar. The velocities reach minimum values just below the boundary (arrow at right), and the porosity indicator ratios have different amplitudes but similar shapes (arrows at left), including an excursion just above the boundary. 


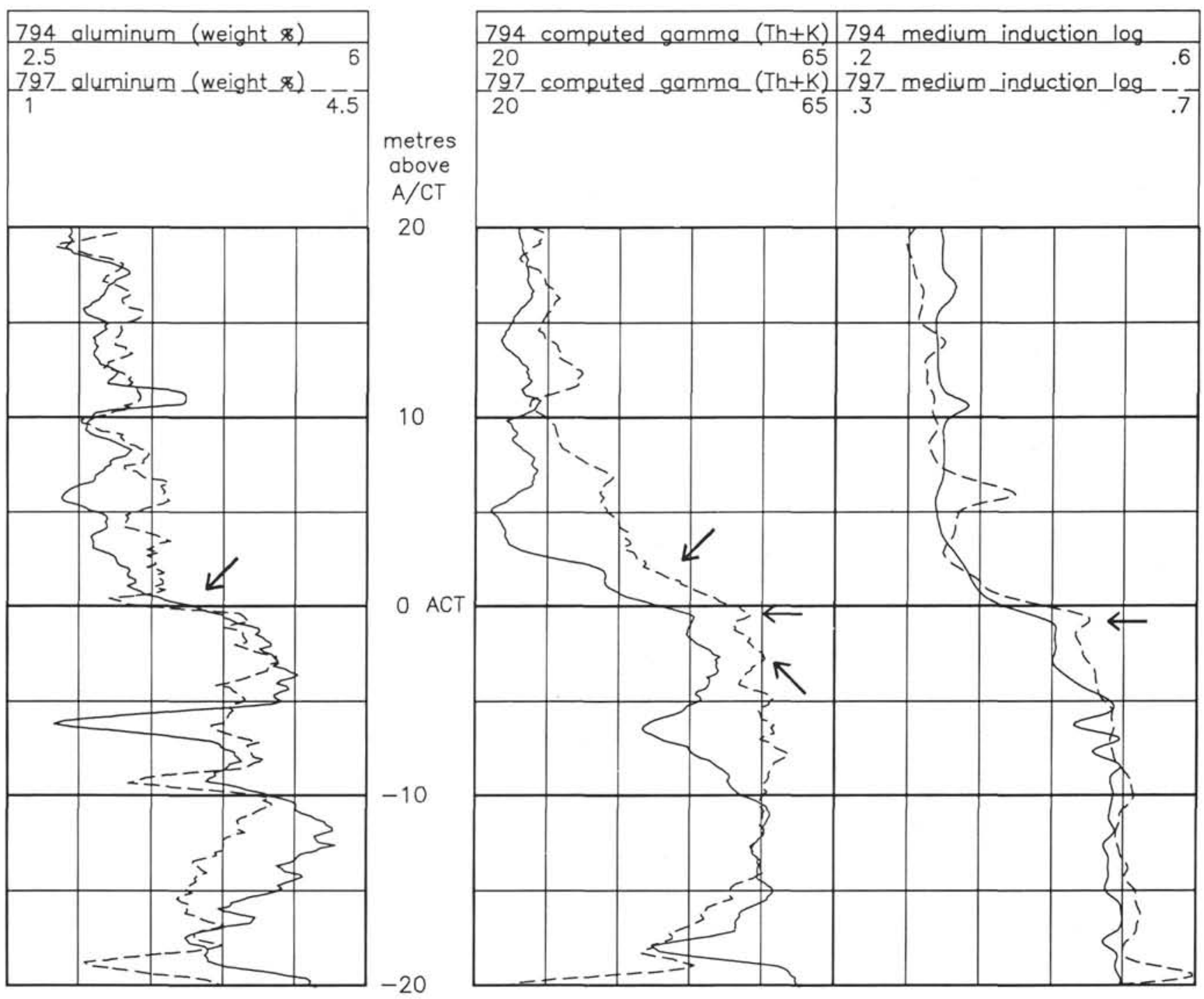

Figure 12. Comparison of the smoothed Al yields, computed $\mathrm{Th}+\mathrm{K}$ gamma-ray responses, and medium induction log resistivities for Sites 794 and 797 . The depths have been adjusted so that the opal-A/opal-CT boundary is at $0 \mathrm{~m}$. The Al yields increase sharply across the opal-A to opal-CT boundary (arrow at left), and the $\mathrm{Th}+\mathrm{K}$ gamma responses increase at a consistent rate (upper arrow, center). The gamma-ray emissions have similar shapes, particularly below the boundary (lower arrows, center). The resistivities also have similar shapes across and below the boundary (arrow at right). 

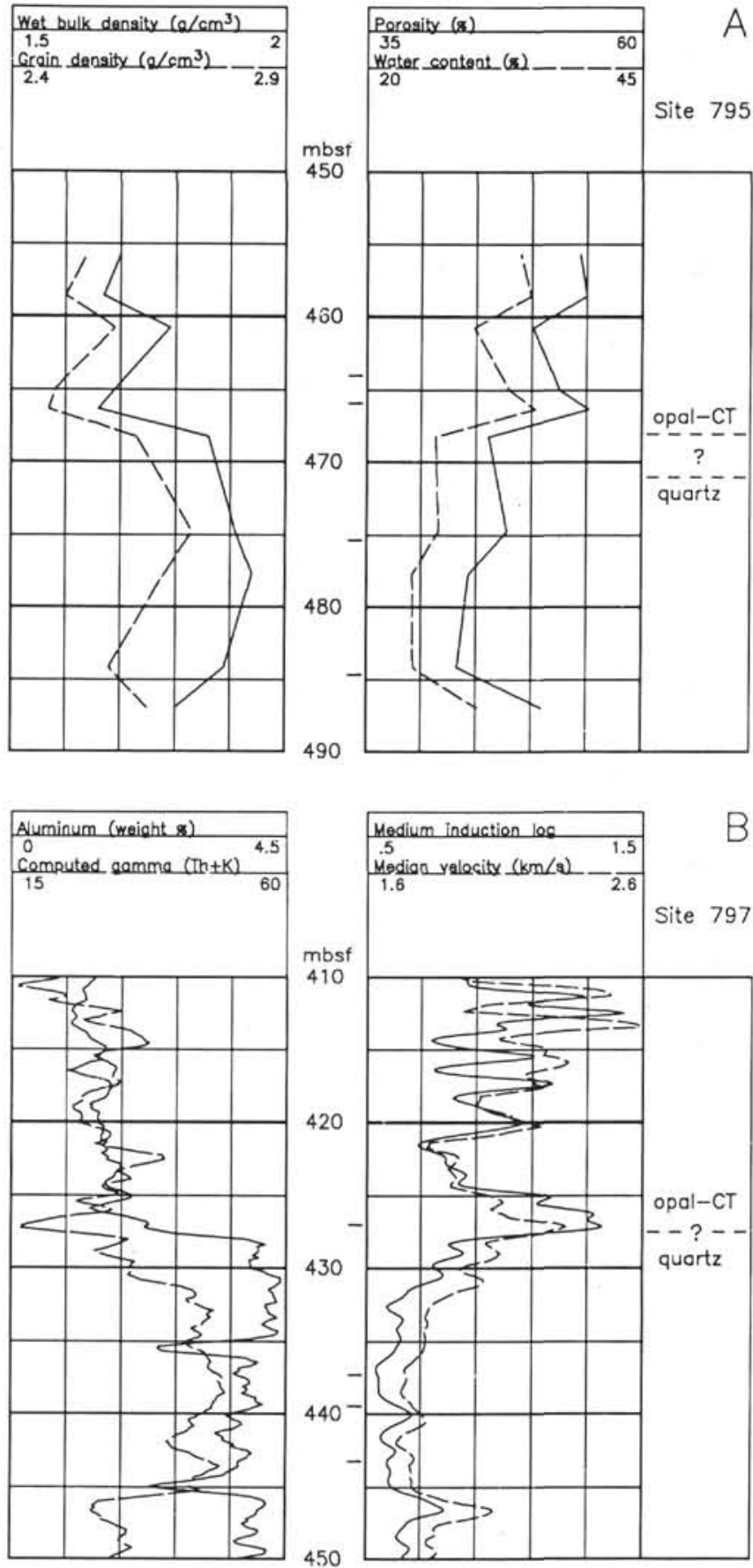

Figure 13. A. Site 795 wet-bulk and grain densities (left) and porosity and water content (right) across the opal-CT/quartz boundary, in API format. GRAPE density and downhole logging data are not available. The exact position of the opal-CT/quartz boundary is uncertain. The boundary assigned on the basis of shipboard data is shown by the lower of the two dashed lines (at right). The index properties, however, suggest that a relatively sharp transition occurs higher in the section, as indicated by the upper dashed line at right. B. Site 797 selected downhole logging data across the opal-CT/quartz boundary. The index properties and the GRAPE density are too sparse to adequately construct a profile across the boundary. The boundary, though uncertain, appears to be located at $427 \mathrm{mbsf}$ and is sharp. The locations of the samples for XRD and SEM work for both sites are indicated by the ticks at the right of the depth columns (center). 


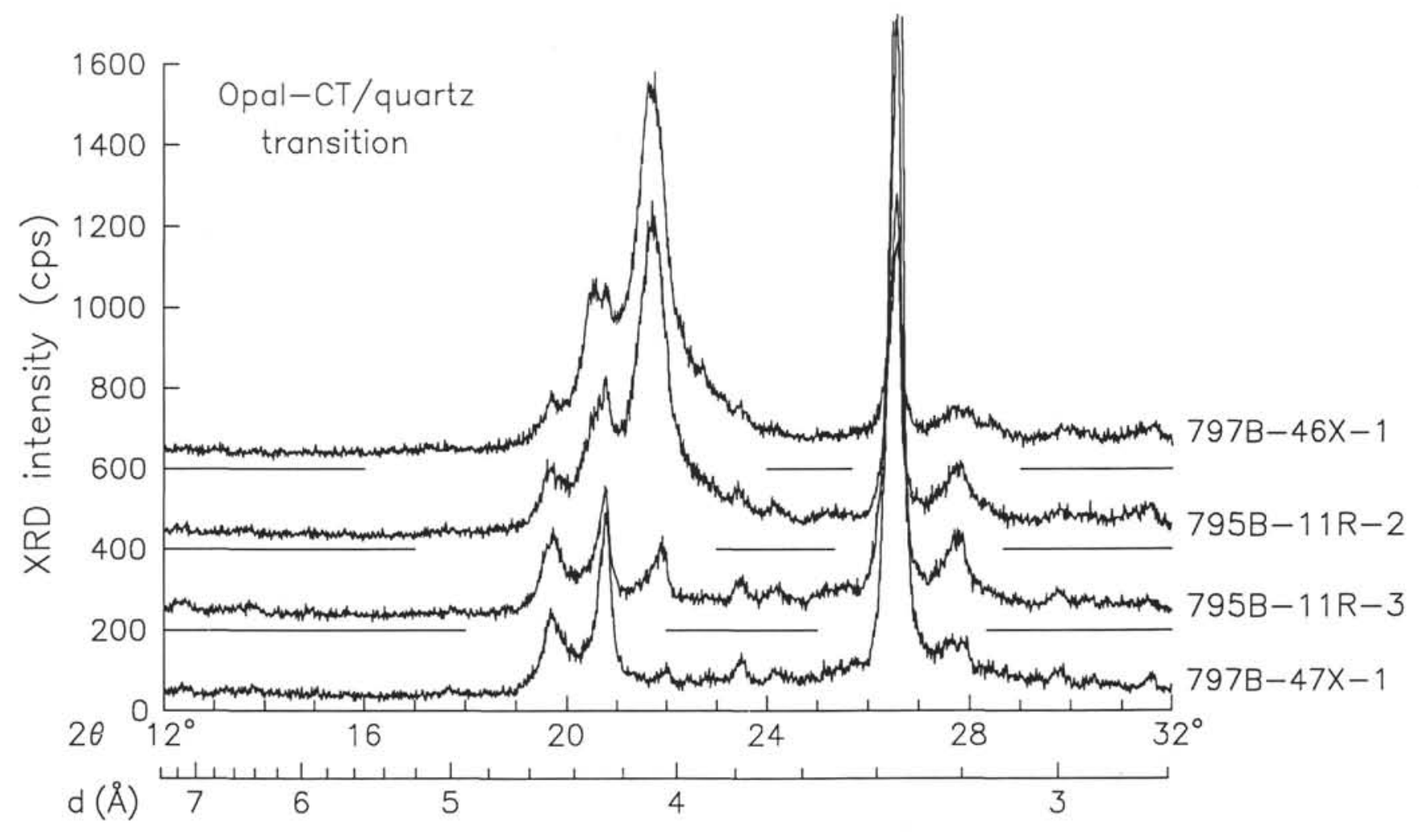

Figure 14. XRD intensity vs. $2 \theta$ and d-spacing for adjacent samples from Sites 795 and 797 . The samples in which the opal-CT is greatly reduced and the quartz has increased are at the bottom: 127-795B-11R-3, 120-122 cm, and 127-797B-47X-1, 107-109 cm. The samples that lie just above the opal-CT/quartz transition are placed on top: 127-795B-11R-2, 81-83 cm, and 127-797B-46X-1, 40-42 cm. The peaks are listed in Tables 1 and 2. Note the substantial drop in the intensity of the CT peaks across the opal-CT/quartz boundary. 

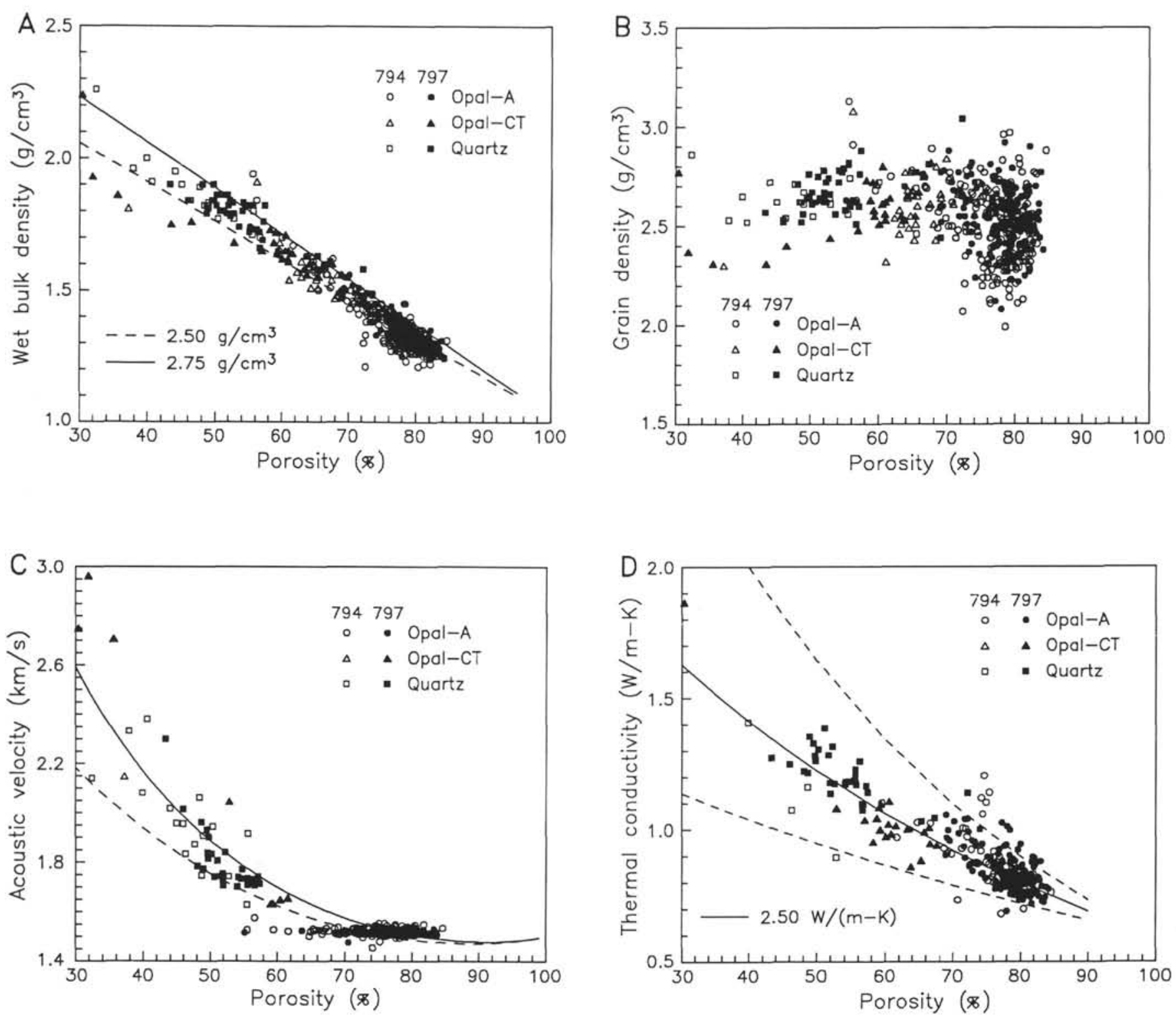

Figure 15. Wet-bulk density (A), grain density (B), acoustic velocity (C), and thermal conductivity (D) vs. porosity for Sites 794 (open symbols) and 797 (solid symbols), for sediments above the opal-A/opal-CT boundary (circles), between the opal-A/opal-CT and opal-CT/quartz boundaries (triangles), and below the opal-CT/quartz boundary (squares). The theoretical mixing lines for grain densities of $2.50 \mathrm{~g} / \mathrm{cm}^{3}$ (dashed line) and $2.75 \mathrm{~g} / \mathrm{cm}^{3}$ (solid line) tend to bracket the wet-bulk density data (A). The grain density is on average lower and more scattered at the higher porosities associated with the sediments above the opal-A/opal-CT boundary, illustrating the effects of varying diatom (low grain density) and clay contents. The sharp change in physical properties across the opal-A/opal-CT boundary is best displayed by the acoustic velocity $(\mathrm{C})$. The velocities of the high-porosity sediments cluster near the water velocity value, approximately $1.5 \mathrm{~km} / \mathrm{s}$. Below the opal-A/opal-CT boundary, the velocities follow the trends indicated by the Nobes (1989) model curves for diatom-rich (solid line) and clay-rich (dashed line) sediments. No clear division exists between opal-CT and quartz properties. The thermal conductivity data (D) cluster about the geometric mean curve (solid) for a grain thermal conductivity of $2.5 \mathrm{~W} /(\mathrm{m} \cdot \mathrm{K})$, a value consistent with a mixture of siliceous and clay sediments. The dashed curves represent grain thermal conductivities of 1.5 (lower) and 4.5 (upper) $\mathrm{W} /(\mathrm{m} \cdot \mathrm{K})$. 


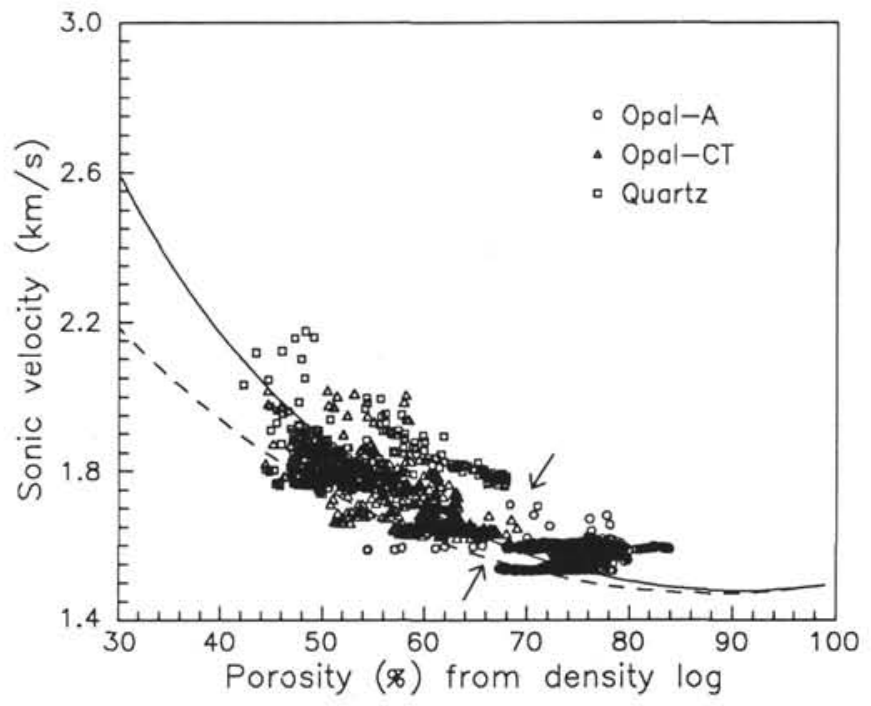

Figure 16. The separation between opal-A and opal-CT acoustic velocities is clear when the sonic velocity is plotted against the porosity derived from the logging density. A distinct gap between the sediments above and below the opal-A/opal-CT boundary appears (indicated by the arrows). The model curves are the same as for Figure 14C, but are shown to indicate general trends only, since the logging velocities and porosities have not been corrected for in-situ pressures. 

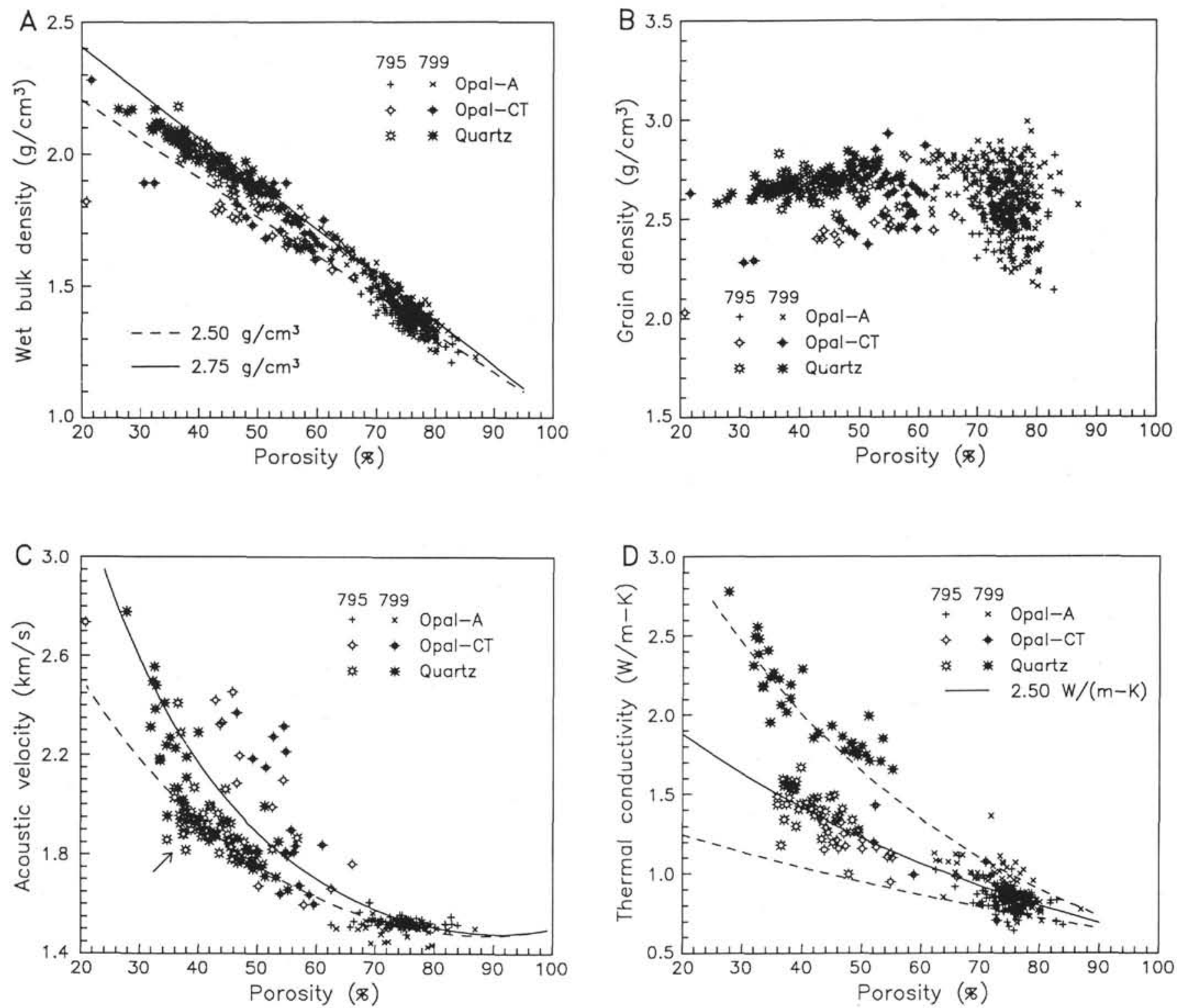

Figure 17. Wet-bulk density (A), grain density (B), acoustic velocity (C), and thermal conductivity (D) vs. porosity for Sites 795 and 799 , for sediments above the opal-A/opal-CT boundary, between the opal-A/opal-CT and opal-CT/quartz boundaries, and below the opal-CT/quartz boundary, as indicated. The physical properties display all of the same trends and patterns identified in the Site 794 and 797 data (Fig. 14). In addition, the acoustic velocity data (C) imply that the Site 795 samples are more clay-rich (as indicated by the arrow at the lower left) and the Site 799 data below the opal-CT/quartz boundary appear to follow a trend from high to low clay content. This trend also appears in the Site 799 thermal conductivities (D) below the opal-CT/quartz boundary, indicative of less clay and silica, and more carbonate, which has a grain thermal conductivity of approximately $5 \mathrm{~W} /(\mathrm{m} \cdot \mathrm{K})$ (Nobes et al., 1991). Carbonate-rich beds, laminae, and concretions were common in Unit III of Site 799, which contained the opal-CT/quartz boundary, and in Unit IV. 

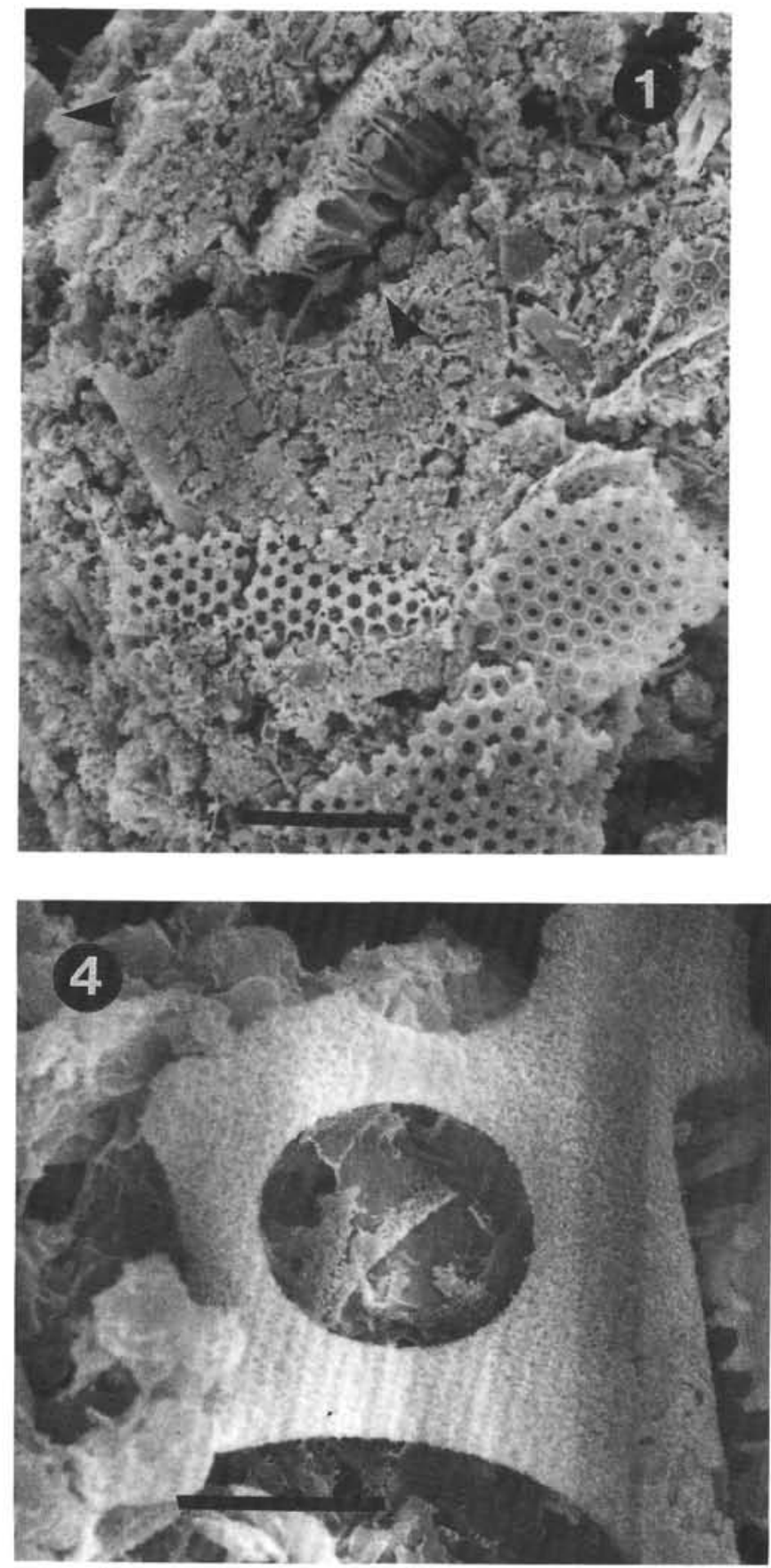
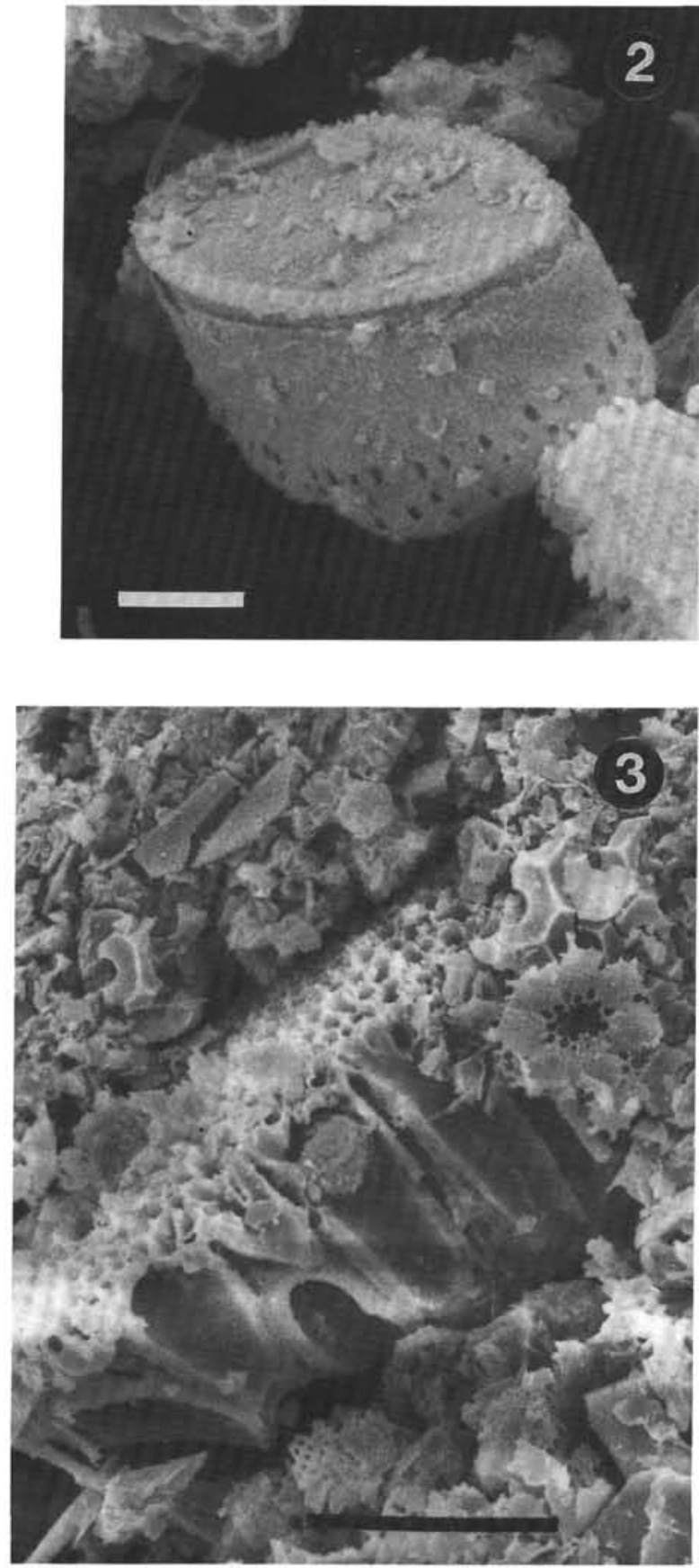

Plate 1. SEM photographs from Samples 127-795A-34X-3, 100-102 cm (1) to (3) (clockwise from upper left), and 127-797B-31X-3, 98-100 cm (4). The samples lie as much as $15 \mathrm{~m}$ above the opal-A/opal-CT transition, and clear signs of dissolution are present. 1. Diatoms have been broken into fragments, showing signs of mechanical porosity reduction. The scale bar is $20 \mu \mathrm{m}$. The areas pictured in (2) and (3) are indicated by the arrows (upper left and upper center, respectively). 2. The diatom, approximately $5 \mu \mathrm{m}$ across, from the upper left of (1). Note the corrosion. The scale bar is $3 \mu \mathrm{m}$. 3 . Detailed view of the upper central portion of (1), showing a broken fragment in cross-section. Again, there are signs of dissolution. The scale bar is $10 \mu \mathrm{m}$. 4. A corroded frustule fragment from Sample 127-797B-31X-3, 98-100 cm. The scale bar is $10 \mu \mathrm{m}$. 

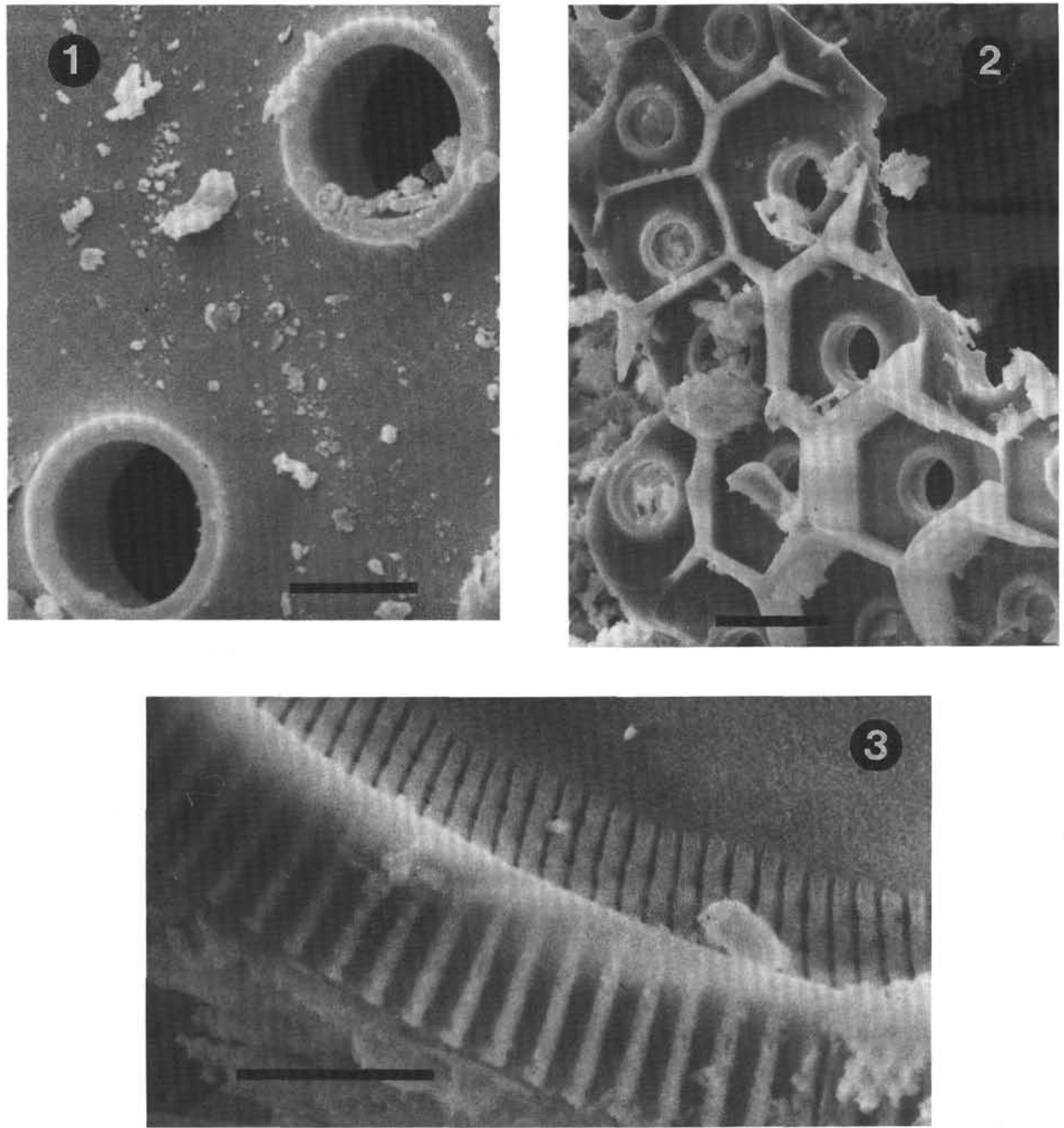

Plate 2. Below the zones where opal-CT is common, samples show little sign of dissolution. For example, Sample 127-795A-35X-3, 100-102 cm (1 through 3) contains abundant uncorroded fragments. Compare these photographs with those in Plate 1. 1. The smooth, clear edges on the openings in the diatom fragment show no indication of dissolution. The scale bar is $2 \mu \mathrm{m}$. 2. An almost pristine fragment has clear sharp edges. Note the open cellular structure that contributes to the high porosity of diatom oozes. The scale bar is $3 \mu \mathrm{m}$. 3. Again, note the clear sharp features still present along the edge of this diatom fragment, with no sign of dissolution. The scale bar is $3 \mu \mathrm{m}$. 

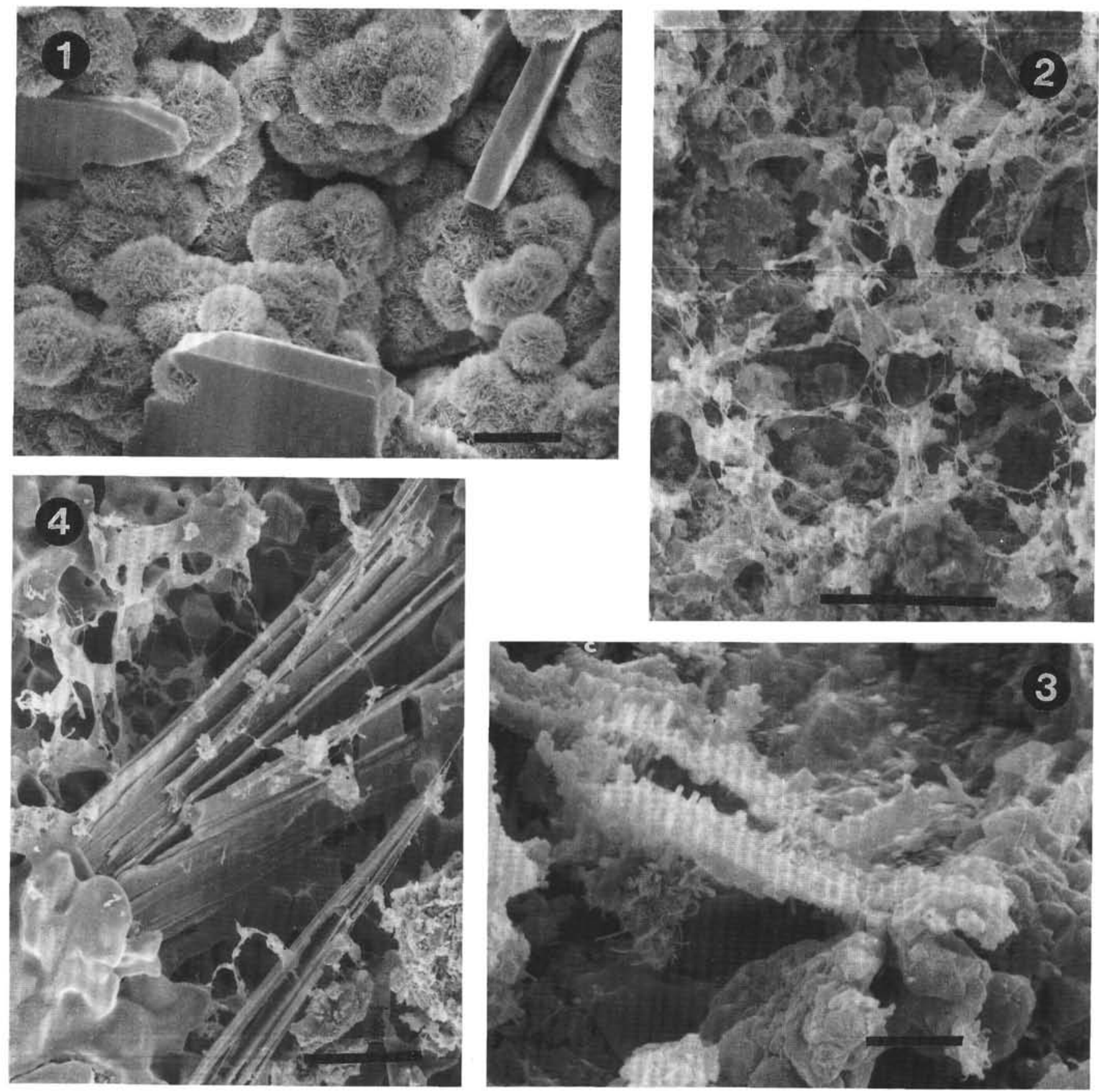

Plate 3. At Site 795, few, if any, clear indications of zeolites were found. In contrast, many different minerals were observed in Site 797 samples. 1. The characteristic "coffin-shaped" crystals of clinoptilolite (Mumpton and Ormsby, 1978; Welton, 1984) were common, as for this example from Sample 127-797B-46X-1, 40-42 cm, shown surrounded by opal-CT. The scale bar is $10 \mu \mathrm{m}$. 2. Clay minerals are also common, in this case illite-smectite (Welton, 1984) from Sample 127-797B-47X-3, 25-27 cm. The scale bar is $20 \mu \mathrm{m}$. 3. Rare occurrences of other minerals are noted, such as halloysite (upper left), a member of the kaolin group (Welton, 1984), from Sample 127-797B-47X-1, 107-109 cm. Halloysite has a characteristic orientation perpendicular to the surface where the crystal adheres. The scale bar is $2 \mu \mathrm{m}$. 4. Bundles of erionite or mordenite (zeolite) fibers (Welton, 1984) surrounded by illite-smectite in Sample 127-797B-47X-3, $25-27 \mathrm{~cm}$. The scale bar is $20 \mu \mathrm{m}$. 

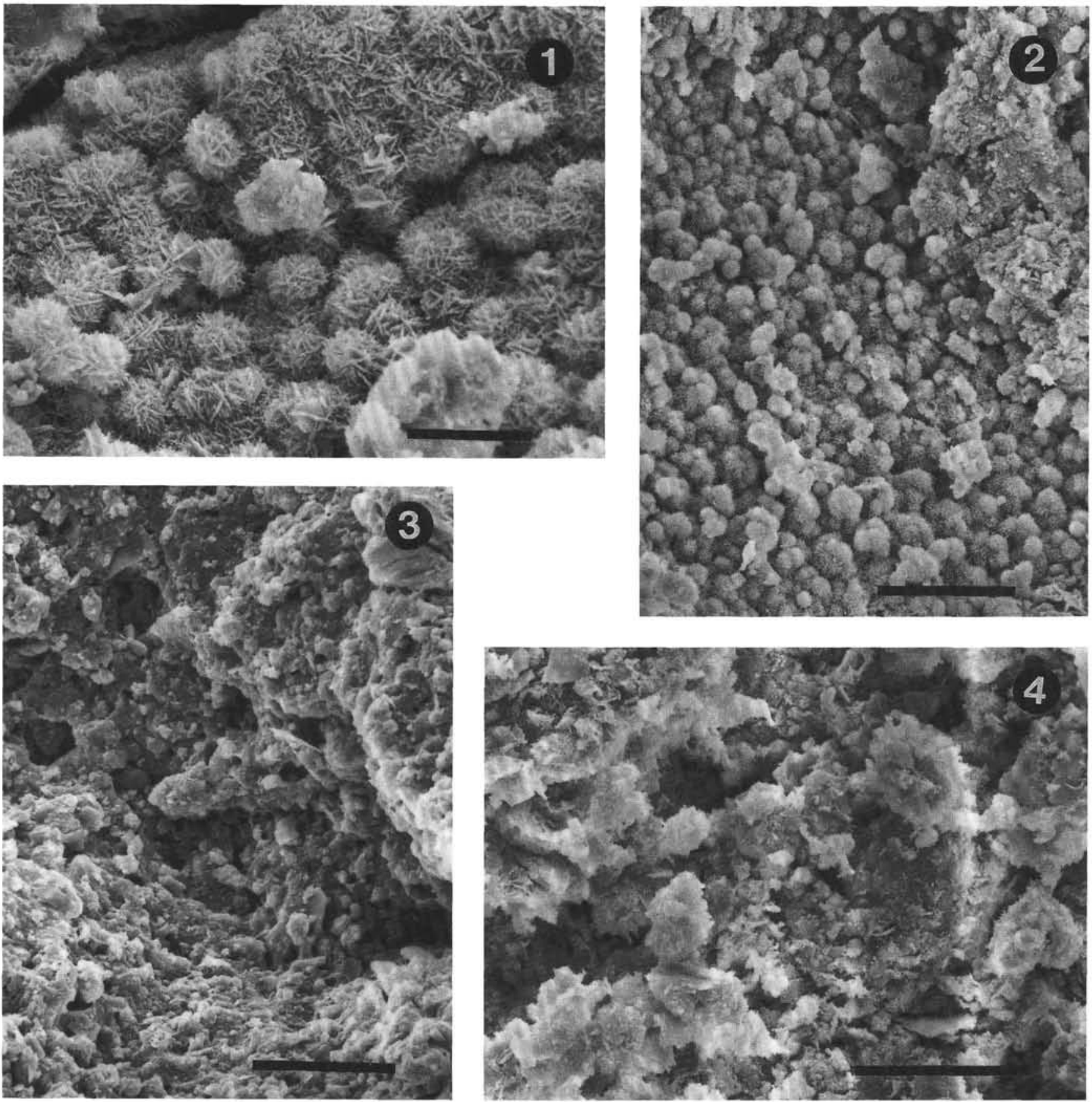

Plate 4. 1. Above the opal-CT/quartz transition, opal-CT is ubiquitous, often as opal-CT blades with characteristic angles of $70.5^{\circ}$ and $109.5^{\circ}$ between blades (e.g., von Rad et al., 1978; Hesse, 1988), as in Sample 127-795B-9R-2, 111-113 cm. The scale bar is $6 \mu \mathrm{m}$. 2. The opal-CT lepispheres grow together and carpet the pore space in Sample 127-795B-11R-2, 81-83 cm. The scale bar is $20 \mu \mathrm{m} . \quad 3,4$. Only $1.7 \mathrm{~m}$ deeper, in Sample 127-795B-11R-3, 120-122 cm, there is no sign of opal-CT. The sample has been overgrown with quartz. The scale bars are $10 \mu \mathrm{m}$ in each case. 